\title{
THE RE-INVESTIGATION OF TUTANKHAMUN'S MUMMY: THE EXPEDITION OF HARRISON IN 1968
}

\author{
ASAAD A. ZAKI \\ DOAA M. ELKASHEF \\ FACULTY OF TOURISM AND HOTELS, UNIVERSITY OF SADAT CITY, EGYPT
}

\begin{abstract}
Over forty years before Harrison's expedition in 1968 to re-examine the remains of Tutankhamun, a British archaeologist, Howard Carter, made one of the world's most famous archaeological discoveries. He discovered the almost intact tomb of Tutankhamun (KV62) in the Valley of the Kings at Thebes in 1922. The mummy of Tutankhamun was first examined by Carter and Derry in 1925. The treasure of Tutankhamun was taken to the Cairo Museum after the discovery, but the mummy remained in the outermost gilded coffin within the red granite sarcophagus until December 1968 when the BBC sponsored a scientific mission led by Harrison to reopen the coffin for the second time to re-examine the mummy. The investigation team of the 1968 expedition wanted to disclose the features that could be clarified by the application of more modern scientific methods of enquiry, which could not be discovered in any other way.
\end{abstract}

The conclusions of the expedition are well known from the anthropological, anatomical and Egyptological points of view, but current scholarship lacks a study of the historiography of the expedition. This study, mainly, depends on the important primary sources represented in the personal papers of Harrison archived in Sydney Jones Library in the University of Liverpool, with presentation of the relevant Egyptological and medical literature.

KEYWORDS: Tutankhamun's Mummy; Ronald George Harrison;

Harrison's team; the 1968 Re-examination of Tutankhamun's

Mummy; Tutankhamun's Blood Group; Tutankhamun's

Tomb; KV55 Mummy

\section{INTRODUCTION}

Since the discovery of his tomb in 1922 by Howard Carter and Lord Carnarvon, the late $18^{\text {th }}$ Dynasty king Tutankhamun has fascinated the world as the immensely rich boy-king. He was originally named 
Tutankhaten ("the Living Image of Aten") but changed his name to Tutankhamun ("the Living Image of Amun") early in his reign on the restoration of the old polytheistic religion, with Amun-Re re-established as "King of the Gods" once again. He married the third daughter of Akhenaten (Amenhotep IV) and Nefertiti, Ankhesenpaaten, who also changed her name to Ankhesenamun. Tutankhamun was the immediate successor of Smenkhkare. ${ }^{1}$ In spite of his fame, little was known about the cause of his death, his parentage and his relations. The English anatomist Ronald George Harrison, Professor of Anatomy at the University of Liverpool, led the 1968 re-examination of the mummy of Tutankhamun, trying to clear up the mystery. ${ }^{2}$

Harrison particularly chose to work on Tutankhamun's mummy because he had examined the mummy from KV55, which he identified as belonging to Smenkhkare, in $1963 .{ }^{3}$ Since Smenkhkare was believed to have been Tutankhamun's brother, and since Harrison demonstrated the facial similarity between Smenkhkare (KV55 mummy) and Tutankhamun after reconstruction, it was therefore essential to re-examine Tutankhamun's remains to establish whether they were in fact brothers. ${ }^{4}$

The first examination of Tutankhamun's mummy was performed by the English anatomist Douglas E. Derry, Professor of Anatomy at the Faculty of Medicine of the Egyptian University, and by Saleh Bey Hamdi, the former director of the Medical School at Qasr el-Aini, with the collaboration of Howard Carter, in the period 11-19 November 1925. The examination took place in the outer corridor of the tomb of Seti II

\footnotetext{
${ }^{1}$ H. W. Fairman, "Tutankhamun and the End of the 18th Dynasty," Antiquity 46 (1972): 16; Joyce Tyldesley, Tutankhamen's Curse: The Developing History of an Egyptian King (London: Profile, 2012), XIII-XIV, 33.

2 "Egyptology: The Kith and Kin of Tutankhamun," The Times, March 3, 1972. A more recent investigation, the King Tutankhamun Family Project, tried to answer these research questions again, Zahi Hawass et al., "Ancestry and Pathology in King Tutankhamun's Family," Journal of the American Medical Association 303, no. 7 (2010): 638-647.

${ }^{3}$ R. G. Harrison, "An Anatomical Examination of the Pharaonic Remains Purported to Be Akhenaten," Journal of Egyptian Archaeology 52 (1966): 95-119; "Not Worried by Tut Tomb Curse, Says Liverpool Professor," Irish Times, December 12, 1968; R. G. Harrison, R. C. Connolly, and A. Abdalla, "Kinship of Smenkhkare and Tutankhamen Demonstrated Serologically," Nature 224 (1969): 325; R. G. Harrison and A. B. Abdalla, "The Remains of Tutankhamun," Antiquity 46 (1972): 8.

${ }^{4}$ Letter from R. G. Harrison to Paul Johnstone on 21 October 1968, D433/3/4, Special Collections and Archives, Sydney Jones Library - University of Liverpool, UK; R. G. Harrison, "The Tutankhamun Post-Mortem," in Chronicle: Essays from Ten Years of Television Archaeology, ed. Ray Sutcliffe (London: British Broadcasting Corporation, 1978), 41.
} 
(KV15). ${ }^{5}$ The mummy rested in the outermost gilded mummiform coffin within the stone sarcophagus, which was covered with a glass sheet, since Derry first examined it. The visitors to Tutankhamun's tomb were able only to see the outermost coffin which has never been opened since the 1920 s. $^{6}$ The mummy was re-examined by Harrison's team in December $1968 .^{7}$

Many researchers from different disciplines tried to shed light on the life and death of one of the most famous kings of ancient Egypt, Tutankhamun. The re-examination in 1968 of the mummy of Tutankhamun was the first forensic analysis using simple $\mathrm{X}$-ray radiographs to establish the possible cause of his death. ${ }^{8}$ The results of the anthropological and skeletal study of the mummy were published in different scientific papers by the expedition members; the expedition conclusions are well known to those who are interested in Egyptology and anatomy. Although these studies are groundbreaking, current scholarship lacks a study of the historiography of the expedition of Harrison in 1968.

The article looks first at Harrison's interest in studying mummies, the research team of the 1968 expedition, and Harrison's permission to reexamine Tutankhamun's mummy. A section then deals with the preexpedition arrangements, the place of the investigation of the mummy, and the difficulties that confronted Harrison before visiting Egypt to reexamine the mummy. The study also demonstrates the role of the British Broadcasting Cooperation (the BBC) which sponsored the expedition. The study then moves on to the investigation process in the tomb of Tutankhamun (KV62) in the Valley of the Kings at Thebes, the work of the team in Liverpool after the expedition in order to conclude their results, and the results of the expedition. Finally, the article explores the postexamination publicity of the expedition and of Harrison himself.

5 Howard Carter, The Tomb of Tut-Ankh-Amen: Discovered by the Late Earl of Carnarvon and Howard Carter, II (London: Cassell \& Company Limited, 1927), XX; F. Filce Leek, The Human Remains from the Tomb of Tut'ankhamūn (Oxford: Griffith Institute, 1972): 3, 11; Tyldesley, Tutankhamen's Curse, 145; F. J. Rühli and S. Ikram, "Purported Medical Diagnoses of Pharaoh Tutankhamun, c. 1325 BC," HOMOJournal of Comparative Human Biology 65 (2014): 52.

${ }^{6}$ Harrison and Abdalla, "The Remains of Tutankhamun," 8.

${ }^{7}$ Harrison, Connolly, and Abdalla, "Kinship of Smenkhkare and Tutankhamen," 325; Harrison and Abdalla, "The Remains of Tutankhamun," 8.

${ }^{8}$ The 1968 examination was followed by another forensic examination in 1978 by the University of Michigan team also using simple X-ray radiographs, Gerald Brandt, "Did Tutankhamun Suffer from Hypophosphatasia? - A Hypothetical Approach," Anthropologischer Anzeiger 70, no. 3 (2013): 249. 
The study presents the important primary sources relevant to Harrison's expedition in 1968 systematically. The primary sources are represented in the personal papers of Harrison held in Sydney Jones Library in the University of Liverpool. These personal records, including letters, notes, photographs and other related accounts, give information that was not manipulated in the published papers of the expedition members in different journals. Harrison's records provide important information concerning the beginning of the project, the sponsorship, the team members, the examination process, the results and even the post-investigation publicity. The relevant secondary literature discussing the findings of the reinvestigation in 1968 of Tutankhamun's mummy from the Egyptological and medical standpoints is also presented. The study relies on the historical and analytical research methods through interpretation and criticizing the relevant sources and presumption of events.

\section{HARRISON'S INTEREST IN STUdYING MUMMIES}

Ronald George Harrison was born on 5 April 1921 in Ulverston City in England. He was appointed as a demonstrator in the Department of Anatomy at Oxford in 1945. At the age of 29, he joined the Department of Anatomy in the University of Liverpool in $1950 .^{9}$ Harrison's interest in studying the mummification process and mummies began in 1960, when he was called in by the Director of Public Prosecutions of Rhyl, Denbighshire, as a forensic scientist, to identify the remains of an aged widow, dead some 25 years. The body had been found by chance in a small cupboard in a boarding house in Rhyl. The cupboard had cold air circulating in it from above and hot air from below, and the body had dried and shriveled and not decomposed-it had become a mummy. As a result, Harrison became interested in the whole process of mummification and studied the techniques which were developed in ancient Egypt. ${ }^{10}$

The mummy of Tutankhamun was not the first royal mummy to be examined by Harrison. He had performed an anatomical re-examination in December $1963^{11}$ of the remains in the Egyptian Museum in Cairo found in the coffin in Tomb 55 in the Valley of the Kings at Thebes, which was discovered in January $1907^{12}$. The 1963 re-examination of the remains

\footnotetext{
9 “In Memoriam: Ronald George Harrison, M.A., D.M.," Journal of Anatomy 137 (1983): 209.

${ }^{10}$ TVT 9, Tutankhamun 1, D4333/3, Special Collections and Archives, Sydney Jones Library - University of Liverpool, UK; Harrison, "The Tutankhamun Post-Mortem," 41.

${ }^{11}$ Harrison, "An Anatomical Examination," 95-119.

${ }^{12}$ Published as the "Tomb of Queen Tiye" in Theodore M. Davis, The Tomb of Queen Tîyi (London: Constable, 1910); C. N. Reeves, "A Reappraisal of Tomb 55 in the Valley of the Kings," Journal of Egyptian Archaeology 67 (1981): 48.
} 
from KV55 was performed with the collaboration of Ahmed Batrawi, Professor of Anatomy in the University of Cairo, and with the assistance of Mahmoud El Sayed Mahmoud, Professor of Radiology in the University of Cairo, who assisted in the radiological examination to certain selected parts of the remains. ${ }^{13}$

The identity of the mummy from Tomb KV55 has been extensively discussed by medical specialists as well as Egyptologists. ${ }^{14}$ At the time of the discovery, two medical men examined the mummy and identified it as belonging to a woman. ${ }^{15}$ Consequently both the tomb and mummy were thought to belong to Queen Tiye, the principal wife of Amenhotep III and mother of Akhenaten, because of the presence of a shrine of Queen Tiye and other funerary equipment in the tomb. ${ }^{16}$ Later, Grafton Elliot Smith, at that time Professor of Anatomy in the Egyptian Government School of Medicine, examined the remains and determined that they belong to a man aged 25 or 26 years at death. ${ }^{17}$ Most Egyptologists thought that the remains belong to Akhenaten, because they were insisting that the coffin bore his name and titles. ${ }^{18}$ Later, Smith had identified the remains as those of Akhenaten, and extended the age limit of the mummy to 29 or 30 years, attempting to reconcile the anatomical evidence with the historical evidence which requires a life-span of more than thirty years for Akhenaten by suggesting a possible delay in the growth of the bones. ${ }^{19}$

\footnotetext{
${ }^{13}$ The examination was carried out in the Egyptian Museum in Cairo and the Qasr el-Aini Hospital of Cairo University, Harrison, "An Anatomical Examination," 98, n. 3 and 108.

${ }^{14}$ Joyce M. Filer, “Anatomy of a Mummy,” Archaeology 55, no. 2 (2002): 26.

${ }^{15}$ H. W. Fairman, "Once Again the So-Called Coffin of Akhenaten," Journal of Egyptian Archaeology 47 (1961): 25; Guenter B. Risse, "Pharaoh Akhenaton of Ancient Egypt: Controversies among Egyptologists and Physicians Regarding his Postulated Illness," Journal of the History of Medicine and Allied Sciences 26 (1971): 9.

${ }^{16}$ Davis, The Tomb of Queen Tîyi; Cyril Aldred and A. T. Sandison, "The Pharaoh Akhenaten a Problem in Egyptology and Pathology," Bulletin of the History of Medicine 36, No. 4 (1962): 301; Maarten J. Raven, "A Sarcophagus for Queen Tiy and Other Fragments from the Royal Tomb at El-Amarna," OMRO 74 (1994): 19; Aidan Dodson, Amarna Sunset: Nefertiti, Tutankhamun, Ay, Horemheb, and the Egyptian CounterReformation (Cairo: The American University in Cairo Press, 2009), 25, 41, 76. Queen Tiye was later identified with the mummy of the Elder Lady found in the tomb of Amenhotep II (KV35), Marianne Eaton-Krauss, The Unknown Tutankhamun (New York: Bloomsbury Academic, 2016), 7.

${ }^{17}$ G. Elliot Smith, "A Note on the Estimate of the Age Attained by the Person whose Skeleton was Found in the Tomb," in The Tomb of Queen Tiyi, ed. Theodore M. Davis (London: Constable, 1910), XXIII-XXIV; idem, The Royal Mummies (Cairo: Service des Antiquités de L'Égypte, 1912), no. 61075, 51-56.

18 Aldred and Sandison, "The Pharaoh Akhenaten," 303; Risse, "Pharaoh Akhenaton of Ancient Egypt," 10.

${ }^{19}$ G. Elliot Smith, Tutankhamen and the Discovery of his Tomb (London: George Routledge \& Sons, 1923), 83-84; Aldred and Sandison, "The Pharaoh Akhenaten," 302-
} 
In 1931, Reginald Engelbach, Chief Keeper of the Cairo Museum, came to the conclusion that the coffin had been made for Smenkhkare, ${ }^{20}$ Tutankhamun's immediate predecessor. Derry restored the broken skull of the KV55 mummy and concluded that the mummy is of a man about 23 years of age when he died. He demonstrated the resemblance of the skull to that of Tutankhamun and suggested that they were probably brothers. He identified the mummy as belonging to Smenkhkare, which is in agreement with Engelbach's conclusions. ${ }^{21}$

H. W. Fairman, Professor of Egyptology at the University of Liverpool, suggested in 1961 that the KV55 mummy belongs to Smenkhkare, based on his re-examination of the inscriptions on the coffin. ${ }^{22}$

Harrison's anatomical examination of the KV55 mummy in 1963 proved that the mummy was of a young man approximately 20 years old at the time of death. Harrison demonstrated the facial similarity between the KV55 mummy and Tutankhamun, by comparing the reconstruction of the face of the mummy with Tutankhamun as depicted on his mummiform coffins. He excluded the possibility of any resemblance between the KV55 mummy and Akhenaten as depicted on the monuments. He concluded that the KV55 mummy belongs to Smenkhkare, from considerations of physique, age at death and the facial appearance, ${ }^{23}$ which agrees with Fairman's view.

303; R. G. Harrison, "Celebrity Lecture: The Scientific Basis of Archaeological Investigation," Medicine, Science and the Law 11, no. 1 (1971): 13; Risse, "Pharaoh Akhenaton of Ancient Egypt," 10.

${ }^{20}$ Reginald Engelbach, "The So-called Coffin of Akhenaten," Annales du Service des Antiquités de l'Égypte 31 (1931): 98-114.

21 Douglas E. Derry, "Note on the Skeleton Hitherto Believed to be that of King Akhenaten," Annales du Service des Antiquités de l'Égypte 31 (1931): 115-119; R. Engelbach, "Material for a Revision of the History of the Heresy Period of the XVIII ${ }^{\text {th }}$ Dynasty," Annales du Service des Antiquités de l'Égypte 40 (1940): 151; Aldred and Sandison, "The Pharaoh Akhenaten," 303-304; Risse, "Pharaoh Akhenaton of Ancient Egypt," 11.

${ }^{22}$ Fairman suggested that the coffin was originally made for Meritaten, eldest daughter of Akhenaten and wife of Smenkhkare, and that her body was later removed and the inscriptions on the coffin were modified for the burial of Smenkhkare. This is perhaps, as he suggested, because some of Smenkhkare's funerary equipment had been used for the burial of Tutankhamun due to his early death, Fairman, "Once Again the So-Called Coffin of Akhenaten," 39.

${ }^{23}$ Harrison, "An Anatomical Examination,” 111, 113-116, pls. XXVIII and XXIX; idem, "Celebrity Lecture," 14-15; Harrison and Abdalla, "The Remains of Tutankhamun," 8; Fairman, "Tutankhamun and the End of the 18th Dynasty," 15; Harrison, "The Tutankhamun Post-Mortem," 41. 
The examinations of the KV55 mummy from Smith to Harrison agree that it was of a man in his twenties at death. The mummy was recently reexamined a number of times, most of the results agreeing with the results of Harrison's examination concerning the age at death and the identity of the mummy, ${ }^{24}$ with the exception of the examination of Hawass's team, which estimated the age at death of the KV55 mummy as 35-45 years and concluded that the mummy "is most probably Akhenaten". ${ }^{25}$ However, most Egyptologists still favor the identification of the KV55 mummy as Smenkhkare. It was considered as too young to be Akhenaten, ${ }^{26}$ who is generally known to have ruled at least 17 years in the Egyptological literature, ${ }^{27}$ and must have died in his thirties or older. ${ }^{28}$

Harrison's previous examination in 1963 of the KV55 remains, thought to be those of Smenkhkare, encouraged him to work on the remains of Tutankhamun to find out if there is a relationship between them. Harrison's team hoped to establish whether Tutankhamun and Smenkhkare were in fact brothers by comparing the respective bone structures of their heads. Another important concern for the team was to establish the cause of death of Tutankhamun, whether he was murdered or died of a brain

\footnotetext{
${ }^{24}$ Anatomist Joyce M. Filer examined the KV55 mummy and stated that it belonged to a man who died in his early twenties, Filer, "Anatomy of a Mummy," 26-29. Eugen Strouhal, "Biological Age of Skeletonized Mummy from Tomb KV 55 at Thebes," Anthropologie: International Journal of the Science of Man 48 (2010): 97-112, concluded that the age at death of the KV55 mummy was "in the range of 19-22 years". He confirmed the highly probability of the kinship of Tutankhamun and the KV55 mummy, which he identified as Smenkhkare, as brothers. Corinne Duhig, "The Remains of Pharaoh Akhenaten are not yet identified: Comments on "Biological Age of the Skeletonised Mummy from Tomb KV55 at Thebes (Egypt)" by Eugen Strouhal," Anthropologie: International Journal of the Science of Man 48 (2010): 113-115, determined the age at death of the KV55 mummy as probably 20 years or over, but not more than 23, excluding the identification of the mummy as Akhenaten.

${ }^{25}$ Hawass's team did not publish the evidence on which their estimation of the age was based, Hawass et al., "Ancestry and Pathology," 640, note b to table 1, 644; EatonKrauss, Unknown Tutankhamun, 8-9. However, a member of Hawass's team stated in a television programme that the mummy is of a man in his thirties at least based on the condition of the spine, Duhig, "The Remains of Pharaoh Akhenaten are not yet identified," 113.

${ }^{26}$ Mark Rose, "Who's in Tomb 55?” Archaeology 55, no. 2 (2002): 26, 27; Dodson, Amarna Sunset, 39, 41; Tyldesley, Tutankhamen's Curse, 173.

${ }^{27}$ Cyril Aldred, "Egypt: The Amarna Period and the End of the Eighteenth Dynasty," in Cambridge Ancient History, 2nd ed., vol. 2, ch. xix (Cambridge: Cambridge University Press, 1971), 63; idem, Akhenaten and Nefertiti (New York: Brooklyn Museum/Viking Press, 1973), 27; Donald B. Redford, Akhenaten: The Heretic King (Princeton: Princeton University Press, 1984), 189, 205; Dodson, Amarna Sunset, 45; Eaton-Krauss, Unknown Tutankhamun, 9.

${ }^{28}$ Duhig, "The Remains of Pharaoh Akhenaten are not yet identified," 113, 114.
} 
tumour. ${ }^{29}$ Harrison became a pioneer of the anatomical study of mummies who hoped to discover much more than Carter and Derry with his X-ray technique. $^{30}$

\section{THE EXPEDITION TEAM}

Professor Harrison of the Department of Anatomy in the University of Liverpool conducted the first X-ray analysis of the mummy of Tutankhamun in December 1968. He led a research team, which included Lynn Reeve, a radiographer from the same Department, Ali Abdalla, a lecturer in the Department of Anatomy in the University of Cairo, the Dentist Frank Leek, and Zaki Iskander, Director of the Scientific and Technical Section of the Department of Antiquities in Cairo. ${ }^{31}$

Leek was not a member of Harrison's team at the beginning, but he asked Harrison to join the team to investigate the teeth of Tutankhamun. ${ }^{32}$ Harrison agreed that Leek should accompany him on the examination of Tutankhamun's mummy, ${ }^{33}$ because Leek was interested in Egyptology and published a paper in the Journal of Egyptian Archaeology on the pathology existing in the teeth of ancient Egyptian skulls. ${ }^{34}$ Leek indicated to Harrison that he would cover all costs of his trip to Egypt and the necessary stay there. ${ }^{35}$

Leek had designed a radioactive equipment in order to obtain a radiograph of the teeth of Tutankhamun. The production of a radiograph of the teeth is normally performed by placing the X-ray film inside the mouth and the Xray apparatus directed towards the teeth outside. However, the available images of Tutankhamun's head suggested that the teeth are tightly clenched together, a position which would not permit the placement of an $\mathrm{X}$-ray film inside the mouth. It was therefore essential for Leek to find a technique whereby the source of energy emitting rays is placed inside the mouth, and the film outside. After inquiries at the Radio-Chemical Centre, the Wantage Research Laboratory of the UK Atomic Energy Authority at

\footnotetext{
29 "The Mystery of Tutankhamun's Tomb," Medical News, January 3, 1969.

30 "Not Worried by Tut Tomb Curse, Says Liverpool Professor," Irish Times, December 12, 1968;

${ }^{31}$ Tutankhamun Post-Mortem, BBC Press Service on 17 October 1969, D433/3/3, Special Collections and Archives, Sydney Jones Library - University of Liverpool, UK.

${ }^{32}$ Harrison and Abdalla, "The Remains of Tutankhamun," 10.

${ }^{33}$ F. Filce Leek, "A Technique for Oral Examination of a Mummy," Journal of Egyptian Archaeology 57 (1971): 107.

${ }^{34}$ F. Filce Leek, "Observations on the Dental Pathology Seen in Ancient Egyptian Skulls," Journal of Egyptian Archaeology 52 (1966): 59-64.

${ }^{35}$ Letter from R. G. Harrison to Paul Johnstone on 6 August 1968, D433/3/4, Special Collections and Archives, Sydney Jones Library - University of Liverpool, UK.
} 
Harwell informed of the development of a technique of panoramic radiograph in the oral cavity which uses a radioactive source of energy. Finally it was decided to use a radioactive isotope, Iodine 125 , as the source of radiating energy for obtaining a radiology of the teeth. This was inserted into the tip of a hypodermic needle in order to pass it up into the oral cavity through the floor of the mouth, the X-ray film being placed outside the mouth. ${ }^{36}$

Abdalla played a vital role in the arrangements for the expedition, such as getting the required permits and the help with the equipment etc., and in the investigation. Harrison expressed his deep appreciation and the gratitude of the expedition members for Abdalla's "invaluable help, assistance and guidance during the period of the investigation." 37 Harrison stated: "I cannot speak too highly of his ability both as an anatomist and as a congenial colleague." 38 Harrison asked his assistance in the assessment of the data of the investigation for the meeting with the BBC on 27 March 1969. ${ }^{39}$ Abdalla figured prominently in the BBC film about the expedition. $^{40}$

Harrison informed Abdalla that the paper on the findings of the serological studies of Tutankhamun's mummy would be a combined thesis including his name. To quote from Harrison, "I feel very indebted to you for all the help with equipment etc., which you gave us while in Cairo and Luxor."41 Abdalla was very grateful that Harrison included him as coauthor of the paper published on 25 October 1969 in Nature, ${ }^{42}$ saying "this is a great honour to me. Sir I shall be overwhelmed with your kindness and help to me." 43 Harrison also informed Abdalla that the paper on the findings of the

\footnotetext{
${ }^{36}$ Leek, "A Technique for Oral Examination of a Mummy," 107; Harrison and Abdalla, "The Remains of Tutankhamun," 11.

${ }^{37}$ Letter from R. G. Harrison to Ali Abdalla on 13 December 1968, D433/3/2, Special Collections and Archives, Sydney Jones Library - University of Liverpool, UK.

${ }^{38}$ Letter from R. G. Harrison to Mohamed Morsi, the Director of Cairo University, on 13 December 1968, D433/3/2, Special Collections and Archives, Sydney Jones Library University of Liverpool, UK.

${ }^{39}$ Letter from R. G. Harrison to Ali Abdalla on 10 March 1969, D433/3/2, Special Collections and Archives, Sydney Jones Library - University of Liverpool, UK.

${ }^{40}$ Letter from R. G. Harrison to Ali Abdalla on 1 December 1969, D433/3/2, Special Collections and Archives, Sydney Jones Library - University of Liverpool, UK.

${ }^{41}$ Letter from R. G. Harrison to Ali Abdalla on 1 August 1969, D433/3/2, Special Collections and Archives, Sydney Jones Library - University of Liverpool, UK.

${ }^{42}$ Harrison, Connolly, and Abdalla, "Kinship of Smenkhkare and Tutankhamen," 325326.

${ }^{43}$ Letter from Ali Abdalla to R. G. Harrison on 1 December 1969, D433/3/2, Special Collections and Archives, Sydney Jones Library - University of Liverpool, UK.
} 
re-investigation in 1968 would be under their joint authorship. ${ }^{44}$ It was published in March 1972 in Antiquity. ${ }^{45}$

\section{Harrison's Permission to Re-examine Tutankhamun's Mummy}

Harrison proposed the project of the re-examination of Tutankhamun's mummy to Tharwat Okasha, at that time the Egyptian Minister of Culture, who accepted the idea of investigating the mummy of Tutankhamun. ${ }^{46}$

The Permanent Committee for Archaeology in the Egyptian Antiquities Service agreed in its session on 2 December 1967 to give Harrison permission to re-examine the mummy of Tutankhamun in his tomb (KV62) in the Valley of the Kings at Thebes, with a condition that "the mummy should not be removed from its place at any case. ${ }^{, 47}$ However, the written permission from the Director General of Antiquities Service in Cairo was sent to Harrison in October $1968 .^{48}$

Harrison realized the difficulty of getting such permission because of Tutankhamun's place in the hearts of the Egyptians and the difficulties of opening the king's sarcophagus, stating "it was extremely fortunate that the Department of Antiquities provided the necessary permission and full cooperation to proceed with this examination." 49 It seems that Harrison was worried about the Egyptian authorities' procedures regarding his permission to work on the remains of Tutankhamun. Abdalla, a member of Harrison's team, assured him in November 1968 that through his permission, he was entitled to work in the tomb and "the only thing as they made clear in their letter is that the mummy should not be moved." 50

\section{The Pre-Expedition Arrangements}

In conventional investigation, the necessary data could be obtained by visual examination. However, in the case of a mummified body, the data could only be obtained by a radiological examination. The radiological facilities were not available during the first examination of the mummy of

\footnotetext{
${ }^{44}$ Letter from R. G. Harrison to Ali Abdalla on 13 January 1972, D433/3/2, Special Collections and Archives, Sydney Jones Library - University of Liverpool, UK.

${ }^{45}$ Harrison and Abdalla, "The Remains of Tutankhamun," 8-14.

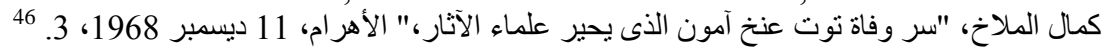

${ }^{47}$ Letter from Gamal Mokhtar to R. G. Harrison on 23 March 1968, D433/3/3, Special Collections and Archives, Sydney Jones Library - University of Liverpool, UK.

${ }^{48}$ Letter from R. G. Harrison to Paul Johnstone on 21 October 1968, D433/3/4, Special Collections and Archives, Sydney Jones Library - University of Liverpool, UK.

${ }^{49}$ Harrison and Abdalla, "The Remains of Tutankhamun," 8.

${ }^{50}$ Letter from Ali Abdalla to R. G. Harrison on 5 November 1968, D433/3/2, Special Collections and Archives, Sydney Jones Library - University of Liverpool, UK.
} 
Tutankhamun in 1925 which was made by direct observation of the mummy. ${ }^{51}$ The re-examination of Tutankhamun's mummy in 1968 by Harrison's team was of paramount importance to find out Tutankhamun's physique and early death and to establish his origins and parentage. Harrison and his colleagues intended to X-ray Tutankhamun's mummy to see whether modern science can solve the mystery of his death and other historical questions. Using more modern methods of investigation may provide additional information and more accurate data; X-radiological examination would be of immense value. ${ }^{52}$

Harrison thought about the project since 1965. Trying to find a sponsor, he suggested the project to the British Broadcasting Corporation (the BBC), which showed interest in the proposed visit to Egypt to re-examine Tutankhamun's remains. ${ }^{53}$ The BBC produced a television programme about the temples of Abu Simbel which "gained the largest audience." 54 This film was presented by the BBC television journalist Magnus Magnusson, and produced by Paul Johnstone, Senior Producer at the Archaeology and History Unit in the BBC. It was screened on BBC-2 on 21 September $1968 .^{55}$

Harrison was invited to visit the University of Khartoum as an examiner in March 1966. He informed the BBC that he could visit Thebes on his way back to re-examine the remains of Tutankhamun. However, he favored to carry out the project later in the year. Harrison told Gordon Watkins, Head of Travel and Feature Programmes in the BBC, that he had no objection to the expedition being in the period July-September 1966 in spite of the hot weather in the region of Thebes, stating "This would not affect me, but it might be a little uncomfortable for your cameramen."

Unfortunately, the Arab-Israeli conflict and the War of June 1967 caused a delay in visiting Egypt as "things are boiling up in the Middle East at the moment." Harrison informed Johnstone that they may not be able to visit

\footnotetext{
${ }^{51}$ F. Filce Leek, "How Old Was Tut'ankhamūn?," Journal of Egyptian Archaeology 63 (1977), 112-113.

${ }^{52}$ Letter from R. G. Harrison to Paul Johnstone on 21 October 1968, D433/3/4, Special Collections and Archives, Sydney Jones Library - University of Liverpool, UK.

${ }^{53}$ Letter from R. G. Harrison to Gordon Watkins on 23 December 1965, D433/3/4, Special Collections and Archives, Sydney Jones Library - University of Liverpool, UK.

${ }^{54}$ Draft letter from Paul Johnstone to the Egyptian Minister of Guidance and the Minister of Tourism on 1 November 1968, D433/3/4, Special Collections and Archives, Sydney Jones Library - University of Liverpool, UK.

55 "Chronicle: Abu Simbel Reborn,” The BBC, Last Modified: June 17, 2020, https://genome.ch.bbc.co.uk/56048492b910415db0ff71a718458d02

${ }^{56}$ Letter from R. G. Harrison to Gordon Watkins on 4 January 1966, D433/3/4, Special Collections and Archives, Sydney Jones Library - University of Liverpool, UK.
} 
Egypt before April 1968. ${ }^{57}$ Johnstone agreed with Harrison's view regarding the political situation in the Middle East and stated that travelling to Egypt at that time would be unwise. ${ }^{58}$ They agreed that they would visit Egypt "as soon as it will be convenient.",59

Johnstone met the Egyptian Consul in London on 1 November 1968 to discuss the proposed visit. ${ }^{60}$ Harrison wrote to the Egyptian Ambassador in London, who expressed his interest in the proposed expedition and promised to contact the authorities in Egypt to facilitate their mission. ${ }^{61}$

\section{The Place of the Mummy's Investigation}

Harrison inquired about the arrangements that had been made regarding the X-raying of the remains of Tutankhamun. He asked Abdalla on 11 December 1967 to make enquiries as to whether the remains would be investigated in Cairo after being transferred from Thebes, or whether they would be investigated in Tutankhamun's tomb (KV62) in the Valley of the Kings at Thebes and then X-rayed at the hospital at Luxor. ${ }^{62}$

The permission to work on the remains of Tutankhamun stated a stipulation that the mummy should not be removed from the tomb. In other words, Harrison was not allowed to remove the mummy to the hospital at Luxor for the radiological examination. Harrison and his team had to replan their project, because Harrison had expected that "there would be no difficulty whatsoever in obtaining permission to remove the remains to the Luxor hospital at least." It was therefore essential for Harrison to be provided with a portable X-ray apparatus in Egypt to radiograph the remains of Tutankhamun in the tomb. ${ }^{63}$ It was impossible to transfer such heavy equipment by air. ${ }^{64}$

\footnotetext{
${ }^{57}$ Letter from R. G. Harrison to Paul Johnstone on 25 May 1967, D433/3/4, Special Collections and Archives, Sydney Jones Library - University of Liverpool, UK.

${ }^{58}$ Letter from Paul Johnstone to R. G. Harrison on 26 May 1967, D433/3/4, Special Collections and Archives, Sydney Jones Library - University of Liverpool, UK.

${ }^{59}$ Letter from R. G. Harrison to Paul Johnstone on 7 July 1968, D433/3/4, Special Collections and Archives, Sydney Jones Library - University of Liverpool, UK.

${ }^{60}$ Letter from Paul Johnstone to R. G. Harrison on 1 November 1968, D433/3/4, Special Collections and Archives, Sydney Jones Library - University of Liverpool, UK.

${ }^{61}$ Letter from R. G. Harrison to Paul Johnstone on 4 November 1968, D433/3/4, Special Collections and Archives, Sydney Jones Library - University of Liverpool, UK.

${ }^{62}$ Letter from R. G. Harrison to Ali Abdalla on 11 December 1967, D433/3/2, Special Collections and Archives, Sydney Jones Library - University of Liverpool, UK.

${ }^{63}$ Letter from R. G. Harrison to Ramadan Saad on 8 April 1968, D433/3/2, Special Collections and Archives, Sydney Jones Library - University of Liverpool, UK.

${ }^{64}$ Harrison and Abdalla, "The Remains of Tutankhamun,"10.
} 
Harrison suggested to Abdalla that they could borrow a suitable portable X-ray apparatus from Mahmoud El Sayed Mahmoud of Cairo University, ${ }^{65}$ who assisted in the radiological examination in 1963 of the KV55 mummy, presumed to be Smenkhkare. $^{66}$ The Radiological examination was necessary to obtain the X-rays of Tutankhamun's remains for analysis and comparison with those of Smenkhkare. ${ }^{67}$

Abdalla reassured Harrison that they could X-ray the remains without needing the local hospital aid, whether Harrison would bring a portable Xray apparatus with him or they borrow one from the Department of Anatomy at Cairo, although the one in Cairo "is an old machine", but Abdalla vowed to check the apparatus and to ensure that it is ready to work properly. ${ }^{68}$

As the mummy would be examined radiologically in the tomb of Tutankhamun, the team would need a suitable lighting. Harrison wrote to Ramadan Saad of the Antiquities Service in Luxor to inform him of the voltage of the electricity supply to the tomb. ${ }^{69}$ Harrison stated that "the lighting there is provided by a generator and was not very good" at the time of his visit to the tomb in December 1963. He presumed that the voltage was a 110 volts DC. ${ }^{70}$ Ramadan Saad informed Harrison on 19 April 1968 that the voltage in the tomb is 220 A.C., which was supplied to the tomb directly from the town, and that the old generator, which gave also the same voltage, was still there to be used in emergency situations. ${ }^{71}$

Harrison asked Abdalla on 6 August 1968 whether it would be possible to borrow the Anthropometric instruments at the Department of Anatomy at Qasr el-Aini, University of Cairo, which he used at the time of the investigation of the KV55 mummy (Smenkhkare) in 1963 and were valuable instruments, otherwise it would mean bringing rather heavy similar instruments. He informed him that they would need to use all of the equipment, including the anthropometric boards, goniometer, and

\footnotetext{
${ }^{65}$ Letter from R. G. Harrison to Ali Abdalla on 8 April 1968, D433/3/2, Special Collections and Archives, Sydney Jones Library - University of Liverpool, UK.

${ }^{66}$ Harrison, "An Anatomical Examination," 98, n. 3 and 108.

${ }^{67}$ Harrison and Abdalla, "The Remains of Tutankhamun," 11.

${ }^{68}$ Letter from Ali Abdalla to R. G. Harrison on 11 April 1968, D433/3/2, Special Collections and Archives, Sydney Jones Library - University of Liverpool, UK.

${ }^{69}$ Letter from R. G. Harrison to Ramadan Saad on 8 April 1968, D433/3/2, Special Collections and Archives, Sydney Jones Library - University of Liverpool, UK.

${ }^{70}$ Letter from R. G. Harrison to Ali Abdalla on 8 April 1968, D433/3/2, Special Collections and Archives, Sydney Jones Library - University of Liverpool, UK.

${ }^{71}$ Letter from Ramadan Saad to R. G. Harrison on 19 April 1968, D433/3/2, Special Collections and Archives, Sydney Jones Library - University of Liverpool, UK.
} 
calipers. ${ }^{72}$ Abdalla informed Harrison that there would be no difficulty in borrowing the anthropometric equipment from the Department of Anatomy at Cairo. ${ }^{73}$

While the X-ray apparatus would be brought from Cairo, Harrison would bring the X-ray films with him from Liverpool, ${ }^{74}$ because it was extremely difficult to find such films in Cairo during that time. ${ }^{75}$ Harrison asked Abdalla to confirm the good condition of the X-ray apparatus and the possibility of its transportation to Luxor and the tomb, and to inform him of the sort of the apparatus and its details in order to make enquiries about it and to get the suitable film before visiting Egypt. ${ }^{76}$ Abdalla informed Harrison that there would be no difficulty in transporting the equipment to Luxor. ${ }^{77} \mathrm{He}$ got a specialist to examine the X-ray apparatus who reported that "it is in very good order and ready for any job specially bones." 78 Abdalla provided Harrison with details of the X-ray apparatus in order to determine its characteristics and the best films to use. ${ }^{79}$

\section{THE ROLE OF THE BBC: THE EXPEDITION SPONSORSHIP}

The British Broadcasting Corporation (the BBC) officials were anxious to know the plans that had been developed for the examination of the remains of Tutankhamun. The investigation process was characterized by its high cost in terms of time, travel and equipment. Paul Johnstone, Senior Producer at the Archaeology and History Unit in the BBC, offered financial aid on extensive scale and to photograph a film of Harrison's

${ }^{72}$ Letter from R. G. Harrison to Ali Abdalla on 6 August 1968, D433/3/2, Special Collections and Archives, Sydney Jones Library - University of Liverpool, UK.

${ }^{73}$ Letter from Ali Abdalla to R. G. Harrison on 23 August 1968, D433/3/2, Special Collections and Archives, Sydney Jones Library - University of Liverpool, UK.

${ }^{74}$ Letter from R. G. Harrison to Ali Abdalla on 30 August 1968, D433/3/2, Special Collections and Archives, Sydney Jones Library - University of Liverpool, UK.

${ }^{75}$ Letter from Ali Abdalla to R. G. Harrison on 23 August 1968, D433/3/2, Special Collections and Archives, Sydney Jones Library - University of Liverpool, UK.

${ }^{76}$ Letter from R. G. Harrison to Ali Abdalla on 30 August 1968, D433/3/2, Special Collections and Archives, Sydney Jones Library - University of Liverpool, UK; Letter from R. G. Harrison to Ali Abdalla on 3 October 1968, D433/3/2, Special Collections and Archives, Sydney Jones Library - University of Liverpool, UK.

${ }^{77}$ Letter from Ali Abdalla to R. G. Harrison on 4 September 1968, D433/3/2, Special Collections and Archives, Sydney Jones Library - University of Liverpool, UK.

${ }^{78}$ Letter from Ali Abdalla to R. G. Harrison on 24 September 1968, D433/3/2, Special Collections and Archives, Sydney Jones Library - University of Liverpool, UK.

${ }^{79}$ Letter from Ali Abdalla to R. G. Harrison on 16 October 1968, D433/3/2, Special Collections and Archives, Sydney Jones Library - University of Liverpool, UK; Letter from R. G. Harrison to Ali Abdalla on 25 October 1968, D433/3/2, Special Collections and Archives, Sydney Jones Library - University of Liverpool, UK. 
work on Tutankhamun's remains. The BBC started the planning of the project with Harrison since $1965 .{ }^{80}$

Johnstone saw that the size of the financial aid needed for the expedition was "very reasonable," 81 which would not exceed £400. Harrison expressed his own delight that the BBC would assist him financially in his expedition to Egypt. ${ }^{82}$ The financial allocation for Harrison was $£ 40$ as a fee for the expedition, but he had not cashed the cheque wishing to utilize this money for purchasing a copy of the film once produced by the BBC. ${ }^{83}$

The BBC proposed to undertake the re-investigation of the remains of Tutankhamun in the period April $23^{\text {rd }}-$ May $11^{\text {th }}, 1968$. Harrison asked Abdalla in December 1967 to persuade the Egyptian authorities to send the necessary formal written permission to undertake the re-examination as soon as possible. "Otherwise, it will not be possible to get these investigations of the ground at all in time for the end of April", Harrison said. ${ }^{84}$ Abdalla suggested that it would be better for the expedition to be in September 1968 because the weather "is very hot" in Egypt and Harrison would have enough time to prepare for the visit as well. ${ }^{85}$ Harrison received the written permission for a scientific investigation of Tutankhamun's mummy from the Director General of Antiquities Service in Cairo in October 1968. ${ }^{86}$

It seems that the $\mathrm{BBC}$ did not have the permission to photograph a film of Harrison's work on Tutankhamun's remains in the tomb, which was essential to their visit, until October 1968. Harrison hoped to get this permission very quickly so that they could accomplish their investigation. ${ }^{87}$

\footnotetext{
${ }^{80}$ Sally MacDonald and Michael Rice, Consuming Ancient Egypt (New York: Routledge, 2016), 200.

${ }^{81}$ Letter from Paul Johnstone to R. G. Harrison on 15 May 1967, D433/3/4, Special Collections and Archives, Sydney Jones Library - University of Liverpool, UK.

${ }^{82}$ Letter from R. G. Harrison to Paul Johnstone on 17 May 1967, D433/3/4, Special Collections and Archives, Sydney Jones Library - University of Liverpool, UK.

${ }^{83}$ Letter from R. G. Harrison to Paul Johnstone on 6 March 1969, D433/3/4, Special Collections and Archives, Sydney Jones Library - University of Liverpool, UK.

${ }^{84}$ Letter from R. G. Harrison to Ali Abdalla on 11 December 1967, D433/3/2, Special Collections and Archives, Sydney Jones Library - University of Liverpool, UK.

${ }^{85}$ Letter from Ali Abdalla to R. G. Harrison on 11 April 1968, D433/3/2, Special Collections and Archives, Sydney Jones Library - University of Liverpool, UK.

${ }^{86}$ Letter from R. G. Harrison to Paul Johnstone on 21 October 1968, D433/3/4, Special Collections and Archives, Sydney Jones Library - University of Liverpool, UK.

${ }^{87}$ Letter from R. G. Harrison to Ali Abdalla on 25 October 1968, D433/3/2, Special Collections and Archives, Sydney Jones Library - University of Liverpool, UK.
} 
The Egyptian Antiquities Service did not impose any fees on Harrison's work because it was considered a scientific work. However, the BBC's visit was considered a commercial business and therefore the BBC was required to pay fees because it intended to take film of Harrison's scientific investigation for commercial exploitation. ${ }^{88}$ The charge for commercial work was $£ 6$ per each photograph. ${ }^{89}$ To get the permission, the BBC staff was required to complete forms similar to the one Harrison had completed to get his own permission. Harrison asked Abdalla to send him six forms for the BBC staff. ${ }^{90}$

Harrison did not want the BBC to pay the Egyptian authorities for taking film of the examination; he suggested that the BBC team could visit Egypt with him "incognito" as part of his scientific team. He tried to justify that suggestion, stating "I would not like you to feel that having financed my trip to Egypt you were prevented at the last moment from filming the expedition." 91

Johnstone expressed his desire to get permission to film in the tomb of Tutankhamun and precincts in the Valley of the Kings. He stated that the BBC was prepared to pay $£ 100$ as a fee for facilities, though he "would be glad to avoid this if possible." 92 It was crucial for the BBC to film the whole operation in the tomb. Johnstone stated: "This is really the most important important thing of all." ${ }^{, 3}$ He tried to convince the Egyptian authorities to give them permission to film the expedition work in the tomb of Tutankhamun, stating that the British people are very interested in programmes about Egyptian archaeology and that this film would encourage tourists from England to visit Egypt. ${ }^{94}$

\footnotetext{
${ }^{88}$ Letter from Ali Abdalla to R. G. Harrison on 5 November 1968, D433/3/2, Special Collections and Archives, Sydney Jones Library - University of Liverpool, UK.

${ }^{89}$ Letter from R. G. Harrison to Ali Abdalla on 12 November 1968, D433/3/2, Special Collections and Archives, Sydney Jones Library - University of Liverpool, UK.

${ }^{90}$ Letter from R. G. Harrison to Ali Abdalla on 12 November 1968, D433/3/2, Special Collections and Archives, Sydney Jones Library - University of Liverpool, UK.

${ }^{91}$ Letter from R. G. Harrison to Paul Johnstone on 21 October 1968, D433/3/4, Special Collections and Archives, Sydney Jones Library - University of Liverpool, UK.

${ }^{92}$ Letter from Paul Johnstone to R. G. Harrison on 22 October 1968, D433/3/4, Special Collections and Archives, Sydney Jones Library - University of Liverpool, UK.

${ }^{93}$ Letter from Paul Johnstone to R. G. Harrison on 14 November 1968, D433/3/4, Special Collections and Archives, Sydney Jones Library - University of Liverpool, UK.

${ }^{94}$ Draft letter from Paul Johnstone to the Egyptian Minister of Guidance and the Minister of Tourism on 1 November 1968, D433/3/4, Special Collections and Archives, Sydney Jones Library - University of Liverpool, UK.
} 


\section{Harrison's Team in Tutankhamun's Burial Chamber}

The BBC along with Harrison agreed that the proposed visit date would be in December 1968. ${ }^{95}$ The BBC crew numbered five, including Johnstone, the producer, the cameraman Mr. Hunt, an assistant cameraman, a sound recordist, and an electrician. ${ }^{96}$

The scientific team and the BBC crew planned to arrive in Cairo on Flight BA 722 on Saturday, 30 November 1968, and to go to Luxor on Tuesday, 3 December 1968. ${ }^{97}$ The team was accommodated in Winter Palace Hotel in Luxor. ${ }^{98}$ Leek's wife joined the team to be with her husband, but Johnstone asked her to do the continuity work for the film. ${ }^{99}$

Harrison asked the BBC to assist them through its good relationships with the Egyptian Broadcasting Corporation in suggesting to the Antiquities Service in Cairo that the tomb might be closed during the week of the investigation and that no visitors should be allowed to visit the tomb. ${ }^{100}$ The visits to the tomb were suspended for a week to allow the team to work more comfortable. ${ }^{101}$ The tomb was equipped with a suitable lighting and X-ray apparatus to begin the investigation process. ${ }^{102}$

The investigation took three days from Wednesday 4 December 1968 to Friday 6 December 1968. The sarcophagus of Tutankhamun was reopened for the second time in the $20^{\text {th }}$ century on 4 December 1968 by Ahmed El Taher, Chief Inspector of Antiquities at Luxor, and Salah Othman, Chief Engineer of Antiquities at Luxor, and their staffs. The first opening of the sarcophagus was done by Howard Carter, the original excavator, 42 years ago. When the Antiquities Service officials lifted the $6 \mathrm{~mm}$. thick glass lid, measuring $274 \times 147 \mathrm{~cm}$, which covered Tutankhamun's sarcophagus, one

\footnotetext{
95 Tutankhamun Post-Mortem, BBC Press Service, on 17 October 1969, D433/3/3, Special Collections and Archives, Sydney Jones Library - University of Liverpool, UK.

${ }^{96}$ Draft letter from Paul Johnstone to the Egyptian Minister of Guidance and the Minister of Tourism on 1 November 1968, D433/3/4, Special Collections and Archives, Sydney Jones Library - University of Liverpool, UK.

${ }^{97}$ Draft letter from Paul Johnstone to the Egyptian Minister of Guidance and the Minister of Tourism on 1 November 1968, D433/3/4, Special Collections and Archives, Sydney Jones Library - University of Liverpool, UK.

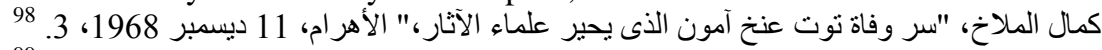

99 "Egyptian Pharaoh Was His Oldest Patient,” Berkhamsted Gazette, November 7, 1969.

${ }^{100}$ Letter from R. G. Harrison to Paul Johnstone on 6 August 1968, D433/3/4, Special

Collections and Archives, Sydney Jones Library - University of Liverpool, UK.

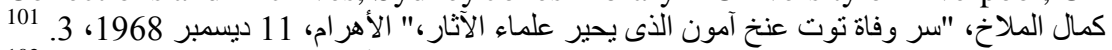

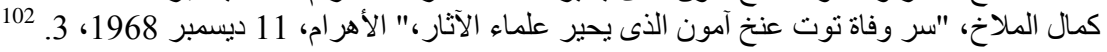


corner of this plate was broken off. ${ }^{103}$ Later, the BBC had instructed Pilkington Brothers Limited Glass Manufacturers, a glass-manufacturing company based in Lancashire, England, to dispatch a sheet of "Armourplate" toughened glass to Cairo at the end of February 1969 to replace the broken one in the tomb. ${ }^{104}$ Pilkington Company supplied 10 $\mathrm{mm}$. thick "Armourplate" glass, $274 \times 147 \mathrm{~cm}$, to cover the sarcophagus of Tutankhamun in the tomb instead of the broken one. It was sent to Alexandria by ship and was transported up the Nile to Luxor. ${ }^{105}$

After opening the coffin, Harrison and his team found the mummy of Tutankhamun in a wooden box which had been used for storing sugar. ${ }^{106}$ The remains of Tutankhamun were wrapped in cotton wool and linen strappings by Carter and his team following their examination in 1925 . When Harrison's team unwrapped the remains, they found that the body was not in one piece. ${ }^{107}$ The body was lying upside down while his face up. ${ }^{108}$ Harrison described the very poor condition and fragility of Tutankhamun's remains as follows: "The head and neck were separate from the torso and so were the limbs" and "One leg broke at the knee when touched". ${ }^{109}$

The mummy of Tutankhamun had been dismembered during its unwrapping and the removal of the amulets and ornaments at the time of the first examination in $1925,{ }^{110}$ because both the mummy and the golden mask were stuck to the bottom of the innermost golden coffin due to the excessive use of unguents by the ancient Egyptian embalmers. ${ }^{111}$

\footnotetext{
${ }^{103}$ R. G. Harrison, Post Mortem on Two Pharaohs, London Press Service, 3, D433/3/6, Special Collections and Archives, Sydney Jones Library - University of Liverpool, UK; Harrison and Abdalla, "The Remains of Tutankhamun," 8.

${ }^{104}$ Letter from Paul Johnstone to R. G. Harrison on 6 February 1969, D433/3/4, Special Collections and Archives, Sydney Jones Library - University of Liverpool, UK; Letter from R. G. Harrison to Ali Abdalla on 21 February 1969, D433/3/2, Special Collections and Archives, Sydney Jones Library - University of Liverpool, UK.

${ }^{105}$ By Appointment to the King - 3300 Years Dead, Pilkington Brothers Limited, on 27 August 1969, D433/3/3, Special Collections and Archives, Sydney Jones Library University of Liverpool, UK.

106 “Scientists Say Tut Died Violently," Baltimore, October 26, 1969.

${ }^{107}$ Harrison and Abdalla, "The Remains of Tutankhamun," 9.

كمال الملاخ، "سر وفاة توت عنخ آمون الذى يحير علماء الآثار،" الأهرام، 11 ديسمبر 1968، 1968، 3. 3108

109 "Scientists Say Tut Died Violently,” Baltimore, October 26, 1969.

كمال الملاخ، "سر وفاة توت عنخ آمون الذى يحير علماء الآثار،" الأهر ام، 11 ديسمبر 1968، 3.

Harrison and Abdalla, "The Remains of Tutankhamun," 9.

${ }^{111}$ Douglas E. Derry, “Appendix I: Report upon the Examination of Tut.Ankh.Amen's Mummy," in The Tomb of Tut.ankh.Amen: Discovered by the Late Earl of Carnarvon and Howard Carter, II, ed. Howard Carter (London: Cassell \& Company Limited, 1927), 148-149; Leek, Human Remains, 11.
} 
Harrison and Abdalla described in detail the state of Tutankhamun's mummy when they examined it in 1968. They stated that the head and neck were separated from the remainder of the body below the seventh cervical vertebra. The right arm was broken at the elbow, and the left arm was broken at the elbow and at the wrist. The left leg was broken at the knee. The right leg was intact, but this leg was also broken at the knee when touched. ${ }^{112}$

Carter was accused of cutting off Tutankhamun's head and packing it with other remains in a cheap sugar wooden box after putting sand in its floor. ${ }^{113}$ Iskander, who accompanied Harrison on his expedition to Luxor, stated that "Carter had no alternative but to separate the head from the rest of the body" for technical reasons and in order to examine the inside of the king's skull. ${ }^{114}$

Harrison expressed his first impressions when the features of Tutankhamun were exposed, stating "It was a moment of great revelation, it was with great reverence that I reached down into the coffin to pick up that famous head." "115 Harrison stated that "the facial appearance is that of a young man, and the lips are parted in a smile, so displaying the upper incisor teeth. The tip of the nose is flattened; this is usual in mummified remains that have been wrapped, and is caused by the pressure of the bandages. The eyelids are open, and expose sunken desiccated eyes in their sockets." ${ }^{, 116} \mathrm{As}$ Harrison was not permitted to remove the mummy from the tomb to X-ray it, he had to do it with a 30 -year-old portable machine in the tomb itself. ${ }^{117}$ Harrison and Abdalla took X-ray photographs and made measurements of Tutankhamun's mummy; every part of the body was X-rayed. They took $50 \mathrm{X}$-ray plates which Harrison brought home to be subjected to intensive

${ }^{112}$ Harrison and Abdalla, "The Remains of Tutankhamun," 9; Richard S. Boyer et al., "The Skull and Cervical Spine Radiographs of Tutankhamen: A Critical Appraisal," American Journal of Neuroradiology 24 (2003): 1142-1143.

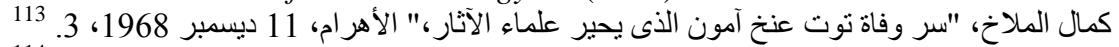

114 "Not Worried by Tut Tomb Curse, Says Liverpool Professor," Irish Times, December 12,1968

${ }^{115}$ R. G. Harrison, Post Mortem on Two Pharaohs, London Press Service, 4, D433/3/6, Special Collections and Archives, Sydney Jones Library - University of Liverpool, UK.

${ }^{116}$ TVT 9, Tutankhamun 3, D433/3/3, Special Collections and Archives, Sydney Jones Library - the University of Liverpool, UK; Harrison and Abdalla, "The Remains of Tutankhamun," 9; Harrison, "The Tutankhamun Post-Mortem," 45.

117 TVT 9, Tutankhamun 1, D433/3/3, Special Collections and Archives, Sydney Jones Library - University of Liverpool, UK; R. G. Harrison, Post Mortem on Two Pharaohs, London Press Service, 4, D433/3/6, Special Collections and Archives, Sydney Jones Library - University of Liverpool, UK; Harrison and Abdalla, "The Remains of Tutankhamun," 10. 
laboratory examination. ${ }^{118}$ They started their investigation with the separated skull, measuring its size and circumference. It was X-rayed for about 15 minutes. ${ }^{119}$ There was, however, a difficulty in making the anthropometry of the mummy (the measurement of the bones dimensions), because of the thick resinous deposit on most of the bones and postmortem fractures in many of them. ${ }^{120}$

The Dentist Leek spent a lot of time perfecting the radioactive isotope Iodine 125 to insert it in the mouth cavity of Tutankhamun's mummy. This would emit a low source of energy to obtain detailed X-rays of Tutankhamun's teeth. It was decided to insert the isotope by using a needle to pass it up into the mouth cavity through the floor of the mouth. When they got there in the tomb, Leek could not insert the radioactive isotope Iodine 125 , because the area under the chin had been heavily covered with resin. $^{121}$ Leek deduced that Derry must have entered the mouth cavity by making an incision beneath the chin to estimate the amount of eruption of the teeth during the original examination of the mummy in 1925, and that he had to repair the damage by covering the area with resin. ${ }^{122}$ However, as Leek stated, "Professor Harrison borrowed an X-ray machine from Cairo University and we got excellent X-rays of the skull and teeth."123

The scientists tried to estimate Tutankhamun's height; it was difficult because many of the bones had grown fragile centuries ago and were broken during the mummy's removal. They calculated the height based on bones that were in good condition; it was about 5 feet and 6.5 inches. This estimation of the height of the mummy corresponds to the previous estimation given by Derry in 1925 ( 5 feet and 4 inches), and agrees with the height of the wooden statues of Tutankhamun which once stood at the entrance of his burial chamber. ${ }^{124}$ On 10 December 1968, Iskander restored Tutankhamun's body similar to its position when he was buried since 3300 years ago without layers of linen cloth used to wrap the mummy. This

\footnotetext{
118 “Autopsy 3.000 Years Later,” The Birmingham Post, December 9, 1968.

كمال الملاخ، "سر وفاة توت عنخ آمون الذى يحير علماء الآثار،" الأهرام، 11 ديسمبر 1968 1968، 3. 3.

${ }^{120}$ R. G. Harrison, Post Mortem on Two Pharaohs, London Press Service, 4, D433/3/6, Special Collections and Archives, Sydney Jones Library - University of Liverpool, UK; Harrison and Abdalla, "The Remains of Tutankhamun," 10; Harrison, "The Tutankhamun Post-Mortem," 45.

${ }^{121}$ Harrison and Abdalla, "The Remains of Tutankhamun," 11; Leek, Human Remains, 17; idem, "How Old Was Tut'ankhamūn?" 113.

${ }^{122}$ Leek, "How Old Was Tut'ankhamūn?" 113-114; Tyldesley, Tutankhamen's Curse, 152.

123 "Egyptian Pharaoh Was His Oldest Patient," Berkhamsted Gazette, November 7, 1969.

${ }^{124}$ Harrison and Abdalla, "The Remains of Tutankhamun," 13; "Egyptology: The Kith and Kin of Tutankhamun," The Times, March 3, 1972.
} 
linen is kept in the Egyptian Museum in Cairo. Iskander put the mummy in the same wooden box. Kamal El Mallakh, archaeological affairs editor of the Cairo newspaper "Al Ahram," claimed that Iskander found a number of collar beads in the sand which was in the bottom of the box and that he collected them in a small sack in one of the box corners. ${ }^{125}$

Iskander put a label recording the new examination of 1968 in Arabic beside the remains of the king, ${ }^{126}$ and closed the sarcophagus with the assistance of the Antiquities Service officials: Ahmed El Taher, Salah Othman, Mohamed Saleh, Antiquities Inspector of El Korna, and his Assistant Abo El Eyoun Abdel Aziz, the Architect Ragaey Zaki, and Mohamed El Tayeb, the Head of the Restoration Unit in Upper Egypt.

\section{The BLoOd Group of Tutankhamun}

It was essential to determine the blood group of Tutankhamun and Smenkhkare in order to investigate the degree of kinship between these two kings. ${ }^{127}$ Harrison's desire to test blood samples of Tutankhamun's body was considered by some as "science fiction," the mummy was about 3.000 years old and dried and there was a man intending to give it a blood test. However, it is well known that the chemical substances which were responsible for specific blood groups are present in all body tissues not only in the blood cells. It was therefore possible to identify the blood group with mummified tissues. ${ }^{128}$

There was a difficulty in obtaining a tissue sample from the remains of Tutankhamun; Harrison was allowed to cut off a piece "the size of a split pea", only ten milligrams, after much argument for laboratory tests. A similar amount was obtained from the remains from KV55, identified as belonging to Smenkhkare, in the 1963 examination. ${ }^{129}$ Harrison brought the tissue sample of Tutankhamun home from the Valley of the Kings for the blood test, which would be performed by Robert Connolly, a lecturer in

\footnotetext{
كمال الملاخ، "سر وفاة نوت عنخ آمون الذى يحير علماء الآثار،" الأهرام، 11 ديسمبر 1968، 3. 3.

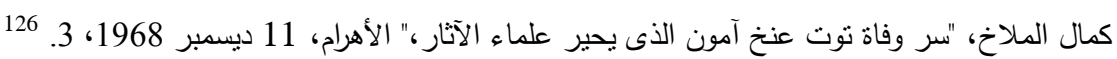

${ }^{127}$ Harrison, Connolly, and Abdalla, "Kinship of Smenkhkare and Tutankhamen,” 325.

${ }^{128}$ Harrison, Connolly, and Abdalla, "Kinship of Smenkhkare and Tutankhamen," 325; TVT 9, Tutankhamun 3, D433/3/3, Special Collections and Archives, Sydney Jones Library - University of Liverpool, UK.

${ }^{129}$ TVT 9, Tutankhamun 1, D433/3/3, Special Collections and Archives, Sydney Jones Library -University of Liverpool, UK; R. G. Harrison, Post Mortem on Two Pharaohs, London Press Service, 4, D433/3/6, Special Collections and Archives, Sydney Jones Library - University of Liverpool, UK.
} 
Physical Anthropology in the Department of Anatomy in the University of Liverpool and a member of Harrison's team. ${ }^{130}$

Until that time, the well-known method to determine the blood group of ancient human remains was called the agglutination technique. This method required the use of large amounts of tissue, usually about one gram (1000 milligrams), while Harrison had only very small amounts of tissue from the remains of Tutankhamun, about ten milligrams. Connolly therefore developed a new serological micromethod at the University of Liverpool for the serological analysis of the tissue from Tutankhamun and Smenkhkare, which does not need large amounts of tissue. ${ }^{131}$

The new method depended on the extraction of the polysaccharides from the dead tissue sample and obtaining red cells from a living person who had a 0 category blood, who had no blood group. The polysaccharides were then attached and absorbed by the red cells of the group 0 person. The mixture was used for a traditional agglutination test which would give the team the blood group of the body from which the tissue sample was obtained. $^{132}$

The results of the new serological micromethod, published in an article by Harrison (and joint authors Connolly and Abdalla) in October 1969 in Nature, showed that both Tutankhamun and the KV55 mummy, widely accepted to belong to Smenkhkare, had the same blood groups $\mathrm{A}_{2}$ and $\mathrm{MN}$. The serological investigation demonstrated the kinship of Smenkhkare and Tutankhamun. However, the serological evidence must be taken in combination with all other evidence to assess the degree of kinship. ${ }^{133}$ The discovery of the presence of identical blood groups in the two mummies was interesting to both Egyptologists and medical specialists.

\footnotetext{
${ }^{130}$ Jo Marchant, The Shadow King: The Bizarre Afterlife of King Tut's Mummy (Boston: Da Capo Press, 2013), 103.

${ }^{131}$ Letter from R. G. Harrison to Paul Johnstone on 9 October 1969, D433/3/4, Special Collections and Archives, Sydney Jones Library - University of Liverpool, UK; R. G. Harrison, Post Mortem on Two Pharaohs, London Press Service, 5, D433/3/6, Special Collections and Archives, Sydney Jones Library - University of Liverpool, UK; R. C. Connolly, "Microdetermination of Blood Group Substances in Ancient Human Tissue," Nature 224 (1969): 325.

${ }^{132}$ R. G. Harrison, Post Mortem on Two Pharaohs, London Press Service, 5, D433/3/6, Special Collections and Archives, Sydney Jones Library - University of Liverpool, UK; Connolly, "Microdetermination of Blood Group Substances," 325.

${ }^{133}$ Harrison, Connolly, and Abdalla, "Kinship of Smenkhkare and Tutankhamen," 325326; "Egyptology: The Kith and Kin of Tutankhamun," The Times, March 3, 1972.
} 


\section{The EXPEDition RESULTS}

The results of the re-examination in 1968 of Tutankhamun's mummy were published in articles by Harrison in Buried History ${ }^{134}$ and Antiquity ${ }^{135}$. Harrison was delighted during his work on the evidence of films and Xrays he took in Egypt, stating "the exercise is really thrilling and exhilarating." 136 This examination was not only useful to establish the cause of Tutankhamun's death, but also to determine his parentage and his relations. It was claimed that Akhenaten was succeeded by Smenkhkare who was in turn succeeded by Tutankhamun. What was not known was the relationship between the three. ${ }^{137}$

Harrison thought that it would take months of hard work to analyze the data collected during the expedition, but he was optimistic about the final results. The X-rays and other evidence had been studied for nine months by Harrison and Connolly. ${ }^{138}$ Harrison did not write his report on Tutankhamun until August 1969 as he was involved in the data collection. ${ }^{139}$ The 1968 re-examination of Tutankhamun's mummy was followed by an extensive study of the family relationships of the late $18^{\text {th }}$ Dynasty, employing the anatomical, radiographic, serological and other methods of investigation. ${ }^{140}$ As a result of the 1925 examination, Derry had suggested that the age of Tutankhamun at the time of death was about 18 years based on the dental evidence and bone analysis, ${ }^{141}$ but he could not establish the cause of his death. ${ }^{142}$

134 R. G. Harrison, "Post Mortem on Two Pharaohs: Was Tutankhamen's Skull Fractured?" Buried History 4 (1971): 114-129.

${ }^{135}$ Harrison and Abdalla, "The Remains of Tutankhamun," 8-14

136 "Mummies are News," Scottish Daily Mail, December 19, 1968.

137 TVT 9, Tutankhamun 1, D433/3/3, Special Collections and Archives, Sydney Jones Library - the University of Liverpool, UK.

138 Tutankhamun Post-Mortem, BBC Press Service, on 17 October 1969, D433/3/3, Special Collections and Archives, Sydney Jones Library - the University of Liverpool, UK.

${ }^{139}$ Letter from R. G. Harrison to Ali Abdalla on 1 August 1969, D433/3/2, Special Collections and Archives, Sydney Jones Library - the University of Liverpool, UK.

${ }^{140}$ Harrison, Connolly, and Abdalla, "Kinship of Smenkhkare and Tutankhamen," 325326; Harrison and Abdalla, "The Remains of Tutankhamun," 8-14; R. C. Connolly, R. G. Harrison, and Soheir Ahmed, "Serological Evidence for the Parentage of Tut'ankhamūn and Smenkhkarē," Journal of Egyptian Archaeology 62 (1976): 184-186.

${ }^{141}$ Derry, “Appendix I: Report upon the Examination of Tut.Ankh.Amen's Mummy," 159; Leek, "A Technique for Oral Examination of a Mummy," 107; idem, "How Old Was Tut'ankhamūn?" 113, 115.

142 Derry, "Appendix I: Report upon the Examination of Tut.Ankh.Amen's Mummy," 160; Leek, Human Remains, 19-20; Dodson, Amarna Sunset, 86; Rühli and Ikram, "Purported Medical Diagnoses of Pharaoh Tutankhamun," 55. 
The X-rays of the skull obtained during the 1968 expedition provided information concerning the state of the teeth. The Dentist Leek stated that Tutankhamun had healthy teeth but he did not live until wisdom teeth appeared to him, ${ }^{143}$ and that he did not suffer the painful conditions of later life in those times such as caries and abscesses. ${ }^{144}$ Harrison and Abdalla stated that "the left mandibular third molar (i.e. the wisdom tooth in the lower jaw) is just in the process of eruption, the right one has erupted, the upper (maxillary) third molars have not yet erupted at all." They stated that the state of eruption of the third molars (wisdom teeth) of the king suggested that the age at death was within the early part of the age range $18-22$ years. ${ }^{145}$

Although Tutankhamun reigned at a time of unsettled political conditions as a result of Akhenaten's religious reforms, Harrison thought that he was not murdered. For a long time Egyptologists have proposed theories that Tutankhamun died of a brain tumour, and Harrison hoped that the X-ray pictures taken by the expedition in 1968 could help to ascertain the cause of his death. ${ }^{146}$

Harrison disproved such theories and suggested that Tutankhamun's death might have been caused by subdural hematoma, which is a collection of blood forming under the membrane covering the brain. He said that the Xrays of Tutankhamun revealed what he called a thinning of the occipital bone at the back of the skull and that there was a small gaping wound at the side of the skull, which may indicate that the king had received a blow in the head. ${ }^{147}$

In the article published in December 1971 in Buried History, Harrison stated: "While examining X-ray pictures of Tutankhamen's skull, I discovered a small piece of bone in the left side of the skull cavity. This could be part of the ethmoid bone, which had become dislodged from the top of the nose when an instrument was passed up the nose into the cranial cavity during the embalming process. On the other hand, the X-rays also suggest that this piece of bone is fused with the overlying skull and this

\footnotetext{
كمال الملاخ، "سر وفاة توت عنخ آمون الذى يحير علماء الآثار،" الأهرام، 11 ديسمبر 1968، 3.

${ }^{144}$ Nick Cole, "Pharaoh's Curse? There Is No Such Thing Says Dentist Who Examined His Teeth!," Watford Evening Echo, October 31, 1969; Harrison and Abdalla, "The Remains of Tutankhamun," 11.

${ }^{145}$ Harrison and Abdalla, "The Remains of Tutankhamun," 11.

146 "King Tut's Curse Defied for a Post Mortem," Nottingham Guardian Journal, December 9, 1968.

147 "Violent Death of Tutankhamen," The Times, October 25, 1969; "Scientists Say Tut Died Violently," Baltimore, October 26, 1969.
} 
could be consistent with a depressed fracture which had healed. This could mean that Tutankhamen died from a brain hemorrhage caused by a blow to his skull from a blunt instrument."

Harrison noticed a small fragment of bone on the left side of the skull cavity on the radiographs of Tutankhamun's skull. At first, Harrison thought that this was a fragment of the ethmoid bone, which was dislodged during the mummification process, and on the BBC film he stated that it was a post mortem artifact. He then suggested that the bone fragment had been dislodged by a blow to his head causing a depressed skull fracture, and that Tutankhamun might have died from a brain hemorrhage. ${ }^{149}$

Harrison's statements have since raised the theory of Tutankhamun's murder by a blow to the head causing a skull fracture before death. ${ }^{150}$ However, Boyer et al. recently re-examined the radiographs of Tutankhamun obtained by Harrison's team in 1968, and noted two intracranial bone fragments on the right side, not on the left, as reported by Harrison. They demonstrated that this is the result of a post mortem event, and suggested that the bone fragments were dislodged during the first examination performed by Carter and Derry in 1925. They found no evidence of a depressed skull fracture, a subdural hematoma, or an injury to or congenital malformation of the cervical spine, disproving the proposed theories of Tutankhamun's murder by a blow to the head or his traumatic death. ${ }^{151}$ The cause of Tutankhamun's death has for decades been a matter of debate among scholars of various disciplines. Other causes of death of Tutankhamun were proposed recently. ${ }^{152}$

\footnotetext{
148 Harrison, "Post Mortem on Two Pharaohs: Was Tutankhamen's Skull Fractured?" $114-129$.

${ }^{149}$ Harrison and Abdalla, "The Remains of Tutankhamun," 11, pl. I; Boyer et al., "The Skull and Cervical Spine," 1143-1145.

150 "Head Blow Killed Tut, British Expert Finds," Washington Post, October 26, 1969; "Scientists Say Tut Died Violently," Baltimore, October 26, 1969; Bob Brier, The Murder of Tutankhamen: A True Story (New York: G. P. Putnam's Sons, 1998); Nicholas Reeves, Akhenaten: Egypt's False Prophet (London: Thames \& Hudson, 2001), 187-189; Boyer et al., "The Skull and Cervical Spine," 1142-1143; Dodson, Amarna Sunset, 86, 88.

${ }^{151}$ Boyer et al., "The Skull and Cervical Spine," 1142-1147, suggested that Derry entered the cranial cavity through the foramen magnum, dislodging fragments of the upper cervical spine into the cranial vault.

${ }^{152}$ For main purported causes of death of Tutankhamun, see Rühli and Ikram, "Purported Medical Diagnoses of Pharaoh Tutankhamun," 57-60, table 1. A more recent examination by Hawass et al. suggested that Tutankhamun most probably died due to a combination of malaria and Köhler's disease II, Hawass et al., "Ancestry and Pathology,” 638-647. This theory, however, raised objections from various sides. Another theory is that Tutankhamun might have suffered from hypophosphatasia, Brandt, "Did Tutankhamun Suffer from Hypophosphatasia? - A Hypothetical Approach,” 249-260.
} 
The 1968 re-examination of Tutankhamun's mummy confirmed some hypotheses regarding Tutankhamun. By comparing the X-ray images of Tutankhamun's mummy with those of the KV55 mummy, identified by Harrison as Smenkhkare, ${ }^{153}$ it was found that the skulls of the two mummies were almost identical and that they had the same short and broad type brachycephalic, but Tutankhamun had a slightly narrower face than Smenkhkare. The investigations of both skeletons showed that both of them had epitrochlear foramina in both humeri (holes in the bones of the arms above the elbow), which may indicate a degree of genetic affinity. ${ }^{154}$

Harrison's X-rays of the teeth and bones of Tutankhamun's mummy showed that Tutankhamun was approximately 18 years old at death. They also showed a remarkable resemblance between Tutankhamun's mummy and the KV55 mummy, generally agreed to belong to Smenkhkare. The scientific investigations of the two mummies led by Harrison suggested a close relationship between Smenkhkare and Tutankhamun, and that they could have been brothers, based on the serological evidence demonstrating that they both belonged to the same blood groups $\mathrm{A}_{2}$ and $\mathrm{MN}$, the $\mathrm{X}$-ray information, such as the almost identical skulls and morphological features in both humeri, and the similarity in facial features. ${ }^{155}$

The members of the 1968 expedition estimated the age at death of Tutankhamun as about 18 years based on the bone analysis and the amount of eruption of the third molars of the jaw (the wisdom teeth). ${ }^{156}$ Leek later suggested that Tutankhamun may have been 16 or 17 years old at death, based on the assumption that the union of the epiphyses and the eruption of the third molars occurred earlier in Egypt. ${ }^{157}$

\footnotetext{
${ }^{153}$ Harrison, “An Anatomical Examination,” 95-119.

154 Harrison, "Celebrity Lecture," 15; Harrison and Abdalla, "The Remains of Tutankhamun," 10; "Egyptology: The Kith and Kin of Tutankhamun," The Times, March 3, 1972; Harrison, "The Tutankhamun Post-Mortem," 45; Scott Woodward, "Genealogy of New Kingdom Pharaohs and Queens," Archaeology 49 (1996): 47.

155 Harrison and Abdalla, "The Remains of Tutankhamun," 8-14; Fairman, "Tutankhamun and the End of the 18th Dynasty," 15; Aldred, "Egypt: The Amarna Period and the End of the Eighteenth Dynasty," 80; "Egyptology: The Kith and Kin of Tutankhamun," The Times, March 3, 1972. More recently Hawass's team identified the KV55 mummy as Akhenaten, and concluded that Tutankhamun's parents were the KV55 mummy (Akhenaten) and the mummy of the Younger Lady found in Amenhotep II's tomb (KV35), Hawass et al., "Ancestry and Pathology," 641, fig. 2.

كمال الملاخ، "سر وفاة نوت عنخ آمون الذى يحير علماء الآثار ،" الأهرام، 11 ديسمبر 1968، 1968، 3.

"Egyptian Pharaoh Was His Oldest Patient," Berkhamsted Gazette, November 7, 1969;

Harrison and Abdalla, "The Remains of Tutankhamun," 11-13.

${ }^{157}$ Leek, "How Old Was Tut'ankhamūn?" 115. Recently Hawass's team estimated the age at death of Tutankhamun as 19 years, Hawass et al., "Ancestry and Pathology," 640.
} 
Fairman argued that the rarity of the blood groups $\mathrm{A}_{2}$ and $\mathrm{MN}$ in ancient Egypt, taken together with the fact that both Smenkhkare and Tutankhamun were members of the royal family of the late $18^{\text {th }}$ Dynasty, ruled in succession, and had many points of similarity, suggested that they were brothers. ${ }^{158}$

Based on the results of Harrison's anatomical examinations of the mummies of Smenkhkare (KV55) and Tutankhamun, taken together with other known historical theories, Fairman came to the conclusion that there was a 10-year co-regency between Amenhotep III and Akhenaten and that both Smenkhkare and Tutankhamun were the sons of Amenhotep III and Sitamun, ${ }^{159}$ the eldest daughter of Amenhotep III and Queen Tiye. ${ }^{160} \mathrm{He}$ excluded the possibility of Queen Tiye being their mother, arguing that Queen Tiye would have been past child-bearing age at the time of Tutankhamun's birth. ${ }^{161}$ In this case, this means that Amenhotep III was both the father and grandfather of Tutankhamun. Fairman expressed the concern, "I'm astounded no Egyptologist has worked it out before."162 To summarize Fairman's conclusion: Akhenaten, Smenkhkare and Tutankhamun were all sons of Amenhotep III, and Smenkhkare and Tutankhamun had the same mother.

Connolly, Harrison, and Soheir Ahmed demonstrated that the serological investigation of the blood groups of the mummies of Amenhotep III and Yuya and Tuya (parents of Queen Tiye), now in the Egyptian Museum in Cairo, suggested two possible family routes for both Smenkhkare and Tutankhamun: Amenhotep III and Queen Tiye, or Amenhotep III and Sitamun. They claimed that the serological evidence (evidence of blood groups) favors Amenhotep III's paternity of Tutankhamun rather than Akhenaten. ${ }^{163}$ However, the identification of paternity should not be based solely on the serological evidence, which alone may suggest filiation but does not prove it. ${ }^{164}$

The use of anatomical and serological methods of investigation as well as physical anthropology alone cannot give definite conclusions concerning

\footnotetext{
${ }^{158}$ Fairman, "Tutankhamun and the End of the 18th Dynasty," 15.

${ }^{159}$ Fairman, "Tutankhamun and the End of the 18th Dynasty," 18.

${ }^{160}$ Redford, Akhenaten, 37.

161 Fairman, "Tutankhamun and the End of the 18th Dynasty," 15-18; "Tutankhamun: The Face Behind the Mask," The Sunday Times, March 26, 1972.

162 "Tutankhamun: The Face Behind the Mask," The Sunday Times, March 26, 1972.

${ }^{163}$ Connolly, Harrison, and Ahmed, "Serological Evidence," 184-186.

${ }^{164}$ John Ray, "The Parentage of Tutankhamūn," Antiquity 49 (1975): 45-47; Edmund S. Meltzer, "The Parentage of Tut'ankhamūn and Smenkhkarē'," Journal of Egyptian Archaeology 64 (1978): 135.
} 
the father of Tutankhamun, and the historical and archaeological evidence has to be taken into consideration. The parentage of Tutankhamun has for decades been the subject of much debate among Egyptologists with many papers and books dealing with the problem from the Egyptological standpoint. The arguments differed whether Tutankhamun was the son of Amenhotep III ${ }^{165}$ or Akhenaten ${ }^{166}$.

The first theory of Amenhotep III being the father of Tutankhamun depends on the restoration texts of Tutankhamun in the temples at Luxor ${ }^{167}$ and Soleb ${ }^{168}$, in which Tutankhamun refers to Amenhotep III as his father. However, it has been argued that the word it "father" was also used to imply "grandfather" or "ancestor", and that it should be interpreted as meaning former king in the context of restoration inscriptions. ${ }^{169}$ In the case of Amenhotep III being the father of Tutankhamun, there must have been a long co-regency between Amenhotep III and Akhenaten. ${ }^{170}$

${ }^{165}$ Engelbach, "Material for a Revision of the History of the Heresy Period of the XVIII ${ }^{\text {th }}$ Dynasty," 160; Christiane Desroches-Noblecourt, Tutankhamen: Life and Death of a Pharaoh (London: Rainbird, 1963), 133; K. A. Kitchen, "Review of Akhenaten, Pharaoh of Egypt: A New Study. By Cyril Aldred," Journal of Egyptian Archaeology 57 (1971): 218; Fairman, "Tutankhamun and the End of the 18th Dynasty," 17, 18; Lanny Bell, "La Parenté de Toutankhamon," Les Dossiers: Historie et Archéologie 101 (1986): 47-49; Cyril Aldred, Akhenaten, King of Egypt (London: Thames \& Hudson, 1988), 293; W. Raymond Johnson, "Honorific Figures of Amenhotep III in the Luxor Temple Colonnade Hall," in For his Ka: Essays Offered in Memory of Klaus Baer, ed. D. P. Silverman. SAOC 55 (Chicago: The Oriental Institute of the University of Chicago, 1994), 142, note 35; Frederick J. Giles, The Amarna Age: Egypt. The Australian Center for Egyptology: Studies 6 (Warminster: Aris \& Phillips, 2001), 124-127.

166 Nicholas Reeves, The Complete Tutankhamun: The King, the Tomb, the Royal Treasure (London: Thames \& Hudson, 1990), 24; Aidan Dodson, "Crown Prince Djhutmose and the Royal Sons of the Eighteenth Dynasty," Journal of Egyptian Archaeology 76 (1990): 95; idem, Amarna Sunset, 15-16, 17.

${ }^{167}$ The inscription of Luxor temple, originally built by Amenhotep III, reads smAwy mnw $\mathrm{n}$ it.f nsw-bity Nb-mAat-Ra "Renewal of monument for his father, King of Upper and Lower Egypt, Nebmaatre", Epigraphic Survey, Reliefs and Inscriptions at Luxor Temple, I: The Festival Procession of Opet in the Colonnade Hall (Chicago: Oriental Institute of the University of Chicago, 1994), 1, 43, pls. 3 and 119.

${ }^{168}$ The restoration inscription on the recumbent lion statue from the temple of Amenhotep III at Soleb, now in the British Museum, reads smAwy mnw $n$ it.f nsw-bity NbmAat-Ra tit-Ra sA Ra Imn-Htp-HqA-WAst "Renewal of the monument for his father, King of Upper and Lower Egypt, Nebmaatre-image-of-Re, Son of Re, Amenhotep-Ruler-of Thebes", I.E.S. Edwards, Hieroglyphic Texts from Stelae etc. in the British Museum, Pt. 8 (London: British Museum, 1939), 14, pl. xv.

${ }^{169}$ Fairman, "Tutankhamun and the End of the 18th Dynasty," 17; Aldred, "Egypt: The Amarna Period and the End of the Eighteenth Dynasty," 80; Dodson, Amarna Sunset, 71, n. 42; Tyldesley, Tutankhamen's Curse, 167.

${ }^{170}$ See Donald B. Redford, History and Chronology of the Eighteenth Dynasty of Egypt: Seven Studies (Toronto: University of Toronto Press, 1967), 89, n. 5; K. A. Kitchen, 
However, there have been arguments against the alleged co-regency in recent years. ${ }^{171}$

The other theory that Akhenaten was the father of Tutankhamun relies on the inscription on the Hermopolis block, probably originally from elAmarna. ${ }^{172}$ The text to the right of the block reads: sA nsw $n$ Xt [.f] mry.f Twt-anxw-itn "King's son of [his] body, his beloved Tutankhuaten". The text to the left refers to a princess whose name is lost. This princess is most certainly Ankhesenpaaten. The Hermopolis block has been considered by scholars as a strong piece of evidence for Akhenten's paternity of Tutankhamun. ${ }^{173}$

\section{The Post-Examination Publicity}

Since their return Harrison and his team were pestered by reporters who were too anxious to learn about the results of the re-investigation of Tutankhamun's remains, while they were unable to make any statements that might be inaccurate before concluding precise results. ${ }^{174}$

The $\mathrm{BBC}$ filmed the whole process of reopening the tomb and the examination and X-raying of the mummy in colour under the direction of Johnstone. ${ }^{175}$ On 27 March 1969, the BBC held a meeting with Harrison to assess the results of the re-examination. ${ }^{176}$ Johnstone sent a draft of the script, which would be commented in the BBC film, to Harrison in May

"Review of The Chronology of the Amarna Letters With Special Reference to the Hypothetical Coregency of Amenophis III and Akhenaten. By E. F. Campbell, Jr.," Journal of Egyptian Archaeology 53 (1967), 181-182; idem, "Review of Akhenaten," 218; Aldred, "Egypt: The Amarna Period and the End of the Eighteenth Dynasty," 80; Ray, "The Parentage of Tutankhamūn," 45; Meltzer, "The Parentage of Tut'ankhamūn and Smenkhkarē'," 135.

${ }^{171}$ E. F. Campbell, Jr., The Chronology of the Amarna Letters With Special Reference to the Hypothetical Coregency of Amenophis III and Akhenaten (Baltimore: The Johns Hopkins University Press, 1964); Redford, History and Chronology, ch. 5; Ray, "The Parentage of Tutankhamūn," 45-47.

${ }^{172}$ Günther Roeder, Amarna-Reliefs aus Hermopolis (Hildesheim: Gerstenberg, 1969), 40, pl. 106, N. 831-VIII C.

${ }^{173}$ Dodson, Amarna Sunset, 15-16, fig. 12; Eaton-Krauss, Unknown Tutankhamun, 3, fig. $1 \mathrm{c}$.

${ }^{174}$ Letter from R. G. Harrison to Ali Abdalla on 13 December 1968, D433/3/2, Special Collections and Archives, Sydney Jones Library - University of Liverpool, UK.

175 "Mummy's tomb opens and Lights Go out," Birmingham Evening Mail, December 11, 1968.

${ }^{176}$ Letter from R. G. Harrison to Ali Abdalla on 10 March 1969, D433/3/2, Special Collections and Archives, Sydney Jones Library - University of Liverpool, UK. 
1969 in order to make his comments or corrections. ${ }^{177}$ The BBC film was decided to be shown at the end of October 1969, and Harrison thought that the film provided an "excellent record" of their expedition. ${ }^{178}$ Harrison had seen cuts from the film about three months before its broadcasting, and expressed his admiration of the film, saying "it should appear very well indeed." 179

The BBC organized a press conference on 23 July 1969 to announce the programmes for the next quarter. The Tutankhamun programme aroused more interest than anything else. The BBC did not provide any information about the results of the re-investigation of Tutankhamun's remains in the conference until they would be revealed at the press conference of Harrison and in the programme. ${ }^{180}$

The BBC planned to hold a press conference for Harrison on 24 October 1969 to publicize the programme on their expedition to Tutankhamun's tomb prior to its screening in "Chronicle" on Saturday, 25 October 1969. ${ }^{181}$ Harrison suggested to hold the press conference in his lecture theatre in Liverpool. Johnstone agreed that it would be best to hold the conference in Liverpool, so that they could invite Reeve and Connolly of Liverpool University and they would not need to get the X-rays to London. ${ }^{182}$

As the press was extremely interested in the findings of Harrison's expedition, the BBC preferred to hold the press conference at 11 o'clock on the morning of the $25^{\text {th }}$ of October 1969 , instead of the $24^{\text {th }}$, to avoid "premature disclosure," because the newspapers could publish the results before the BBC programme being broken. ${ }^{183}$

The BBC documentary movie "Tutankhamen Post-Mortem" was shown for the first time on BBC-2 on 25 October 1969 at 8. 15 p.m. The film included shots of the original discovery of the tomb by Carter and

\footnotetext{
${ }^{177}$ Letter from Paul Johnstone to R. G. Harrison on 1 May 1969, D433/3/4, Special Collections and Archives, Sydney Jones Library - University of Liverpool, UK.

${ }^{178}$ Letter from R. G. Harrison to Ali Abdalla on 5 June 1969, D433/3/2, Special Collections and Archives, Sydney Jones Library - University of Liverpool, UK.

${ }^{179}$ Letter from R. G. Harrison to Ali Abdalla on 1 August 1969, D433/3/2, Special Collections and Archives, Sydney Jones Library - University of Liverpool, UK.

${ }^{180}$ Letter from Paul Johnstone to R. G. Harrison on 24 July 1969, D433/3/4, Special Collections and Archives, Sydney Jones Library - University of Liverpool, UK.

${ }^{181}$ Letter from R. G. Harrison to Ali Abdalla on 1 August 1969, D433/3/2, Special Collections and Archives, Sydney Jones Library - University of Liverpool, UK.

${ }^{182}$ Letter from Paul Johnstone to R. G. Harrison on 20 June 1969, D433/3/4, Special Collections and Archives, Sydney Jones Library - University of Liverpool, UK.

${ }^{183}$ Letter from W. Green to Paul Johnstone on 3 October 1969, D433/3/4, Special Collections and Archives, Sydney Jones Library - University of Liverpool, UK.
} 
discussion of the scientific work of Harrison's team on the remains of Tutankhamun and the results of the expedition. ${ }^{184}$

Harrison congratulated Johnstone for the success of the programme after screening it on the BBC, stating "I have heard nothing but praise from everyone who saw it." ${ }^{185}$ According to Johnstone, "the programme seems to have gone over very well." The programme gained an audience of about a million and a half, which was large for BBC-2 on Saturday night. ${ }^{186}$

EL Mallakh of Al Ahram newspaper contacted Abdalla in November 1969 and asked for a summary of the serological report. He published the report together with Abdalla's photograph under the head line "Professor Harrison's Expedition." Abdalla claimed that this aroused great publicity for the expedition and for him amongst the medical students in Egypt. ${ }^{187}$

It seems that the expedition caused good publicity for Harrison; he was invited to give lectures in the university and in other places, and was also interviewed in various media outlets. The expedition had wide repercussions in the city and University of Liverpool. Harrison asked Johnstone's permission to show the BBC film in a lecture to the University in November 1969 on "the Kinship of Tutankhamen". ${ }^{188}$

Iskander was not satisfied with the theory of Tutankhamun's murder which spread out in the press during that time. Abdalla wrote to Harrison asking him about his opinion so that he could explain to Iskander. ${ }^{189}$ The BBC invited Gamal Mokhtar, Director General of Antiquities Service in Cairo, and Iskander to have dinner with the producers of the BBC at the BBC Television Centre, and to see the Tutankhamun film which appeared on the BBC television, on 12 December 1969. Harrison joined the dinner as well. ${ }^{190}$ Harrison told Abdalla that he met Iskander at the BBC dinner and

\footnotetext{
${ }^{184}$ MacDonald and Rice, Consuming Ancient Egypt, 200.

${ }^{185}$ Letter from R. G. Harrison to Paul Johnstone on 30 October 1969, D433/3/4, Special Collections and Archives, Sydney Jones Library - University of Liverpool, UK.

${ }^{186}$ Letter from Paul Johnstone to R. G. Harrison on 4 November 1969, D433/3/4, Special Collections and Archives, Sydney Jones Library - University of Liverpool, UK.

${ }^{187}$ Letter from Ali Abdalla to R. G. Harrison on 1 December 1969, D433/3/2, Special Collections and Archives, Sydney Jones Library - University of Liverpool, UK.

${ }^{188}$ Letter from R. G. Harrison to Paul Johnstone on 7 November 1969, D433/3/4, Special Collections and Archives, Sydney Jones Library - University of Liverpool, UK.

${ }^{189}$ Letter from Ali Abdalla to R. G. Harrison on 1 December 1969, D433/3/2, Special Collections and Archives, Sydney Jones Library - University of Liverpool, UK.

${ }^{190}$ Letter from Paul Johnstone to R. G. Harrison on 14 November 1969, D433/3/4, Special Collections and Archives, Sydney Jones Library - University of Liverpool, UK; Letter from R. G. Harrison to Ali Abdalla on 1 December 1969, D433/3/2, Special Collections and Archives, Sydney Jones Library - University of Liverpool, UK.
} 
that Iskander asked him about the murder theory. Harrison explained to Iskander personally that Tutankhamun was not murdered and what he did say that Tutankhamun had skull lesions which indicated that he received blows to his head, and that the popular press had taken his statements to indicate that he had been murdered. According to Harrison, "This is, of course, complete rubbish and I am sure that you understand." 191

Harrison asked Johnstone's permission to show the Tutankhamun film in a club called the XX Club of which he was a member, and which included twenty distinguished medically qualified people of the city of Liverpool. The film was planned to be shown at a meeting of the club on the $1^{\text {st }}$ April, 1970. Harrison invited Johnstone and his wife to attend the meeting, and to talk for 15 to 20 minutes about the difficulties of producing the film, ${ }^{192}$ and Johnstone accepted the invitation. ${ }^{193}$

Harrison was asked to give another lecture in March 1970 in Wigan, a town in Greater Manchester, where he needed to show the BBC film regarding his scientific mission in Egypt. ${ }^{194}$

The Bureau of the West German Television Network in London intended to produce a documentary film in 1972 to commemorate the $50^{\text {th }}$ anniversary of the discovery of Tutankhamun's tomb by Howard Carter and Lord Carnarvon. Harrison was asked to participate in the film and to make an interview for the film in Liverpool. ${ }^{195}$ Werner Prym, who was directing and preparing this film, thought that Harrison's work on the remains of Tutankhamun would contribute an important aspect which should be included in the film. ${ }^{196}$

The German Television team had spent two days in Liverpool, 14 and 15 June 1971, taking a film of Harrison talking about his scientific expedition in 1968 regarding the re-examination of the mummy of Tutankhamun, which was financed by the BBC. The German Television team insisted to

${ }^{191}$ Letter from R. G. Harrison to Ali Abdalla on 19 January 1970, D433/3/2, Special Collections and Archives, Sydney Jones Library - University of Liverpool, UK.

${ }^{192}$ Letter from R. G. Harrison to Paul Johnstone on 15 December 1969, D433/3/4, Special Collections and Archives, Sydney Jones Library - University of Liverpool, UK.

${ }^{193}$ Letter from Paul Johnstone to R. G. Harrison on 23 December 1969, D433/3/4, Special Collections and Archives, Sydney Jones Library - University of Liverpool, UK.

${ }^{194}$ Letter from R. G. Harrison to Paul Johnstone on 13 February 1970, D433/3/4, Special Collections and Archives, Sydney Jones Library - University of Liverpool, UK.

${ }^{195}$ Letter from R. G. Harrison to Paul Johnstone on 20 May 1971, D433/3/4, Special Collections and Archives, Sydney Jones Library - University of Liverpool, UK.

${ }^{196}$ Letter from Paul Anderson, Chief Correspondent and Head of Bureau of the WestGerman Television Network in London, to R. G. Harrison on 18 May 1971, D433/3/4, Special Collections and Archives, Sydney Jones Library - University of Liverpool, UK. 
show the Tutankhamun X-rays which were obtained by the 1968 expedition sponsored by the BBC. Harrison asked Prym to sign a declaration stating that he would contact the BBC to get their permission for Harrison to show these X-rays in any television film they might prepare, because the $\mathrm{BBC}$ hold the copyright of showing these $\mathrm{X}$-rays in any television programme. Prym promised that he would contact Johnstone to clear the matter of copyright. ${ }^{197}$ This film had been shown on West German Television on 21 March 1972. ${ }^{198}$

\section{CONCLUSION}

The mummy of Tutankhamun was subjected to the first X-ray examination in 1968 by a scientific research team sponsored by the BBC and led by Professor Harrison of the Department of Anatomy in the University of Liverpool. Harrison's interest in studying mummies started about eight years before his expedition to re-examine Tutankhamun's mummy in 1968. The mummy of Tutankhamun was not the first pharaoh's mummy to be investigated by Harrison; he had examined the KV55 mummy, which he identified as Smenkhkare, five years earlier (in 1963).

The planning of the project proposed by Harrison to re-examine Tutankhamun's remains took three years from 1965 to 1968. The reexamination of Tutankhamun's mummy was finally accomplished in the period 4-6 December 1968 due to the delay caused by the Arab-Israeli conflict and the 1967 War. The BBC officials favored not to travel to Egypt at that time.

The Egyptian Government approved the proposed project in December 1967, with a clear stipulation that the mummy should not be removed from the tomb, which required re-planning of the arrangements for the examination. As Harrison's team was not given permission to remove the mummy from the tomb, they were provided with a suitable lighting in the burial chamber and a portable X-ray unit to radiograph the mummy in the tomb.

Abdalla, a member of Harrison's team, played a vital role in the arrangements for the expedition, starting from getting the required permits, checking the suitable X-ray equipment, and even his assistance and guidance during the period of the re-investigation.

\footnotetext{
${ }^{197}$ Declaration by Werner Prym on 15 June 1971; Letter from R. G. Harrison to Paul Johnstone on 16 June 1971, D433/3/4, Special Collections and Archives, Sydney Jones Library - University of Liverpool, UK.

198 Letter form R. G. Harrison to Werner Prym on 5 April 1972, D433/3/4, Special Collections and Archives, Sydney Jones Library - University of Liverpool, UK.
} 
Harrison's team described the very poor condition and fragility of Tutankhamun's remains at the time of reopening the coffin for the second time, and reported of the dismemberment of Tutankhamun's mummy in the process of unwrapping the mummy and removing the artifacts during the original examination of the mummy by Carter and Derry in 1925.

The Dentist Leek, a member of Harrison's team, had not been able to use the radio-active isotope he had designed with the assistance of the UK Atomic Energy Authority at Harwell, which was decided to be inserted in the mouth cavity of Tutankhamun's mummy through the floor of the mouth by using a needle to obtain detailed X-rays of his teeth, because of the heavy layer of resin under the chin. Leek presumed that the layer of resin had been applied to repair the damage which occurred during the 1925 examination. However, the team managed to X-ray the skull and teeth by an X-ray machine which Harrison borrowed from Cairo University.

Harrison's team estimated Tutankhamun's height as approximately 5 feet and 6.5 inches and the age at death as about 18 years, based on the X-rays of the teeth and bones of the mummy. However, Leek later suggested to reduce the age at death to 16 or 17. Harrison suggested that Tutankhamun died as a result of a traumatic injury to the head, based on his observation of a bone fragment in the skull cavity on the radiographs. However, the common theories of a skull fracture and subdural hematoma were later disputed.

The comparison of Tutankhamun's mummy with the KV55 mummy (identified as Smenkhkare) revealed many points of similarity. The results of the 1968 re-examination of Tutankhamun's mummy affirmed a close kinship between Tutankhamun and Smenkhkare, suggesting that they were brothers, from the similarity of blood group, the almost identical skulls, and physiological similarities.

The BBC produced a documentary movie about the examination and $\mathrm{X}$ raying of Tutankhamun's mummy in colour, which was screened on 25 October 1969. The script which was commented in this film was revised by Harrison about five months before its broadcasting.

The expedition of 1968 caused Harrison and the other team members to have a good academic reputation; Harrison was invited to give lectures about the expedition in different places and was interviewed in various media outlets, Abdalla had more publicity among his medical students in Egypt. 


\section{BIBLIOGRAPHY}

\section{SOURCES}

Papers of Professor R. G. Harrison, D433 (D433/3/1-D433/3/2-D433/3/3D433/3/4-D433/3/5-D433/3/6), Special Collections and Archives, Sydney Jones Library - University of Liverpool, UK.

\section{REFERENCES}

- Aldred, Cyril. "Egypt: The Amarna Period and the End of the Eighteenth Dynasty." In Cambridge Ancient History, 2nd ed., vol. 2, ch. xix. Cambridge: Cambridge University Press, 1971.

- _ Akhenaten and Nefertiti. New York: Brooklyn Museum/Viking Press, 1973.

- _ _ _ Akhenaten, King of Egypt. London: Thames \& Hudson, 1988.

- and A. T. Sandison, "The Pharaoh Akhenaten a Problem in Egyptology and Pathology." Bulletin of the History of Medicine 36, No. 4 (1962): 293-316.

- "Autopsy 3.000 Years Later." The Birmingham Post, December 9, 1968.

- Bell, Lanny. "La Parenté de Toutankhamon." Les Dossiers: Historie et Archéologie 101 (1986): 47-49.

- Boyer, Richard S., Ernst A. Rodin, Todd C. Grey, and R. C. Connolly. "The Skull and Cervical Spine Radiographs of Tutankhamen: A Critical Appraisal." American Journal of Neuroradiology 24 (2003): 1142-1147.

- Brandt, Gerald. "Did Tutankhamun Suffer from Hypophosphatasia? A Hypothetical Approach." Anthropologischer Anzeiger 70, no. 3 (2013): 249-260.

- $\quad$ Brier, Bob. The Murder of Tutankhamen: A True Story. New York: G. P. Putnam's Sons, 1998.

- Carter, Howard. The Tomb of Tut-Ankh-Amen: Discovered by the Late Earl of Carnarvon and Howard Carter, II. London: Cassell \& Company Limited, 1927.

- Cole, Nick. "Pharaoh's Curse? There Is No Such Thing Says Dentist Who Examined His Teeth!." Watford Evening Echo, October 31, 1969.

- Connolly, R. C. "Microdetermination of Blood Group Substances in Ancient Human Tissue." Nature 224 (1969): 325. 
- Connolly, R. C., R. G. Harrison, and Soheir Ahmed. "Serological Evidence for the Parentage of Tut'ankhamūn and Smenkhkarē." Journal of Egyptian Archaeology 62 (1976): 184-186.

- Davis, Theodore M. The Tomb of Queen Tîyi. London: Constable, 1910.

- Derry, Douglas E. "Appendix I: Report upon the Examination of Tut.Ankh.Amen's Mummy." In The Tomb of Tut.ankh.Amen: Discovered by the Late Earl of Carnarvon and Howard Carter, II, edited by Howard Carter, 143-161. London: Cassell \& Company Limited, 1927.

- _ . "Note on the Skeleton Hitherto Believed to be that of King Akhenaten." Annales du Service des Antiquités de l'Égypte 3I (1931): $115-119$.

- Desroches-Noblecourt, Christiane. Tutankhamen: Life and Death of a Pharaoh. London: Rainbird, 1963.

- Dodson, Aidan. "Crown Prince Djhutmose and the Royal Sons of the Eighteenth Dynasty," Journal of Egyptian Archaeology 76 (1990): 8796.

- _ Amarna Sunset: Nefertiti, Tutankhamun, Ay, Horemheb, and the Egyptian Counter-Reformation. Cairo: The American University in Cairo Press, 2009.

- Duhig, Corinne. "The Remains of Pharaoh Akhenaten are not yet identified: Comments on "Biological Age of the Skeletonised Mummy from Tomb KV55 at Thebes (Egypt)" by Eugen Strouhal." Anthropologie: International Journal of the Science of Man 48 (2010): 113-116.

- Eaton-Krauss, Marianne. The Unknown Tutankhamun. New York: Bloomsbury Academic, 2016.

- Edwards, I.E.S. Hieroglyphic Texts from Stelae etc. in the British Museum, Pt. 8. London: British Museum, 1939.

- "Egyptian Pharaoh Was His Oldest Patient." Berkhamsted Gazette, November 7, 1969.

- "Egyptology: The Kith and Kin of Tutankhamun." The Times, March 3, 1972.

- Engelbach, Reginald. "The So-called Coffin of Akhenaten." Annales du Service des Antiquités de l'Égypte 31 (1931): 98-114.

- _ _ "Material for a Revision of the History of the Heresy Period of the XVIII ${ }^{\text {th }}$ Dynasty." Annales du Service des Antiquités de l'Égypte 40 (1940): 133-165.

- Epigraphic Survey, Reliefs and Inscriptions at Luxor Temple, I: The Festival Procession of Opet in the Colonnade Hall. Chicago: Oriental Institute of the University of Chicago, 1994. 
- Fairman, H. W. "Once Again the So-Called Coffin of Akhenaten." Journal of Egyptian Archaeology 47 (1961): 25-40.

- _ "Tutankhamun and the End of the 18th Dynasty." Antiquity 46 (1972): 15-18.

- Filer, Joyce M. "Anatomy of a Mummy." Archaeology 55, no. 2 (2002): 26-29.

- Gabolde, Marc. D’Akhenaton à Toutânkhamon. Lyon: Université Lumière-Lyon 2, 1998.

- Giles, Frederick J. The Amarna Age: Egypt. The Australian Center for Egyptology: Studies 6. Warminster: Aris \& Phillips, 2001.

- Harrison, R. G. "An Anatomical Examination of the Pharaonic Remains Purported to Be Akhenaten." Journal of Egyptian Archaeology 52 (1966): 95-119.

- ___ "Celebrity Lecture: The Scientific Basis of Archaeological Investigation." Medicine, Science and the Law 11, no. 1 (1971): 1115 .

- _ . "Post Mortem on Two Pharaohs: Was Tutankhamen's Skull Fractured?." Buried History 4 (1971): 114-129.

- _ . "The Tutankhamun Post-Mortem." In Chronicle: Essays from Ten Years of Television Archaeology, edited by Ray Sutcliffe, 41-52. London: British Broadcasting Corporation, 1978.

- Harrison, R. G., R. C. Connolly, and A. Abdalla. "Kinship of Smenkhkare and Tutankhamen Demonstrated Serologically." Nature 224 (1969): 325-326.

- Harrison R. G. and A. B. Abdalla. "The Remains of Tutankhamun." Antiquity 46 (1972), 8-14.

- Hawass, Zahi, Yehia Z. Gad, Somaia Ismail, Rabab Khairat, Dina Fathalla, Naglaa Hasan, Amal Ahmed, Hisham Elleithy, Markus Ball, Fawzi Gaballah, Sally Wasef, Mohamed Fateen, Hany Amer, Paul Gostner, Ashraf Selim, Albert Zink, and Carsten M. Pusch. "Ancestry and Pathology in King Tutankhamun's Family." Journal of the American Medical Association 303, no. 7 (2010): 638-647.

- "Head Blow Killed Tut, British Expert Finds." Washington Post, October 26, 1969.

- "In Memoriam: Ronald George Harrison,M.A., D.M.." Journal of Anatomy 137 (1983).

- Johnson, W. Raymond. "Honorific Figures of Amenhotep III in the Luxor Temple Colonnade Hall." In For his Ka: Essays Offered in Memory of Klaus Baer, edited by D. P. Silverman, SAOC 55, 133144. Chicago: The Oriental Institute of the University of Chicago, 1994. 
- “King Tut's Curse Defied for a Post Mortem." Nottingham Guardian Journal, December 9, 1968.

- Kitchen, K. A. "Review of The Chronology of the Amarna Letters With Special Reference to the Hypothetical Coregency of Amenophis III and Akhenaten. By E. F. Campbell, Jr.." Journal of Egyptian Archaeology 53 (1967): 178-182.

- _ _ _Review of Akhenaten, Pharaoh of Egypt: A New Study. By Cyril Aldred." Journal of Egyptian Archaeology 57 (1971): 217-219.

- Leek, F. Filce. "Observations on the Dental Pathology Seen in Ancient Egyptian Skulls.” Journal of Egyptian Archaeology 52 (1966): 59-64.

- _ _ _A Technique for Oral Examination of a Mummy." Journal of Egyptian Archaeology 57 (1971): 105-109.

- _ The Human Remains from the Tomb of Tut'ankhamūn. Oxford: Griffith Institute, 1972.

- _ "How Old Was Tut'ankhamūn?." Journal of Egyptian Archaeology 63 (1977): 112-115.

- MacDonald, Sally and Michael Rice, Consuming Ancient Egypt. New York: Routledge, 2016.

- Marchant, Jo. The Shadow King: The Bizarre Afterlife of King Tut's Mummy. Boston: Da Capo Press, 2013.

- Meltzer, Edmund S. "The Parentage of Tut'ankhamūn and Smenkhkarē'." Journal of Egyptian Archaeology 64 (1978): 134-135.

- “Mummies are News." Scottish Daily Mail, December 19, 1968.

- "Mummy's Tomb Opens and Lights Go Out." Birmingham Evening Mail, December 11, 1968.

- "Not Worried by Tut Tomb Curse, Says Liverpool Professor." Irish Times, December 12, 1968.

- Raven, Maarten J. "A Sarcophagus for Queen Tiy and Other Fragments from the Royal Tomb at El-Amarna." OMRO 74 (1994): 720.

- $\quad$ Ray, John. "The Parentage of Tutankhamūn.” Antiquity 49 (1975): 4547.

- Redford, Donald B. History and Chronology of the Eighteenth Dynasty of Egypt: Seven Studies. Toronto: University of Toronto Press, 1967.

$\bullet$ Press, 1984. Akhenaten: The Heretic King. Princeton: Princeton University

- Reeves, Nicholas. "A Reappraisal of Tomb 55 in the Valley of the Kings." Journal of Egyptian Archaeology 67 (1981): 48-55.

- _ _ The Complete Tutankhamun: The King, the Tomb, the Royal Treasure. London: Thames \& Hudson, 1990. 
- _ Akhenaten: Egypt's False Prophet. London: Thames \& Hudson, 2001.

- Risse, Guenter B. "Pharaoh Akhenaton of Ancient Egypt: Controversies among Egyptologists and Physicians Regarding his Postulated Illness." Journal of the History of Medicine and Allied Sciences 26 (1971): 3-17.

- Roeder, Günther. Amarna-Reliefs aus Hermopolis. Hildesheim: Gerstenberg, 1969.

- Rose, Mark. "Who's in Tomb 55?.” Archaeology 55, no. 2 (2002): 2227.

- $\quad$ Rühli, F. J. and S. Ikram. "Purported Medical Diagnoses of Pharaoh Tutankhamun, c. 1325 BC." HOMO-Journal of Comparative Human Biology 65 (2014): 51-63.

- "Scientists Say Tut Died Violently." Baltimore, October 26, 1969.

- Smith, G. Elliot. "A Note on the Estimate of the Age Attained by the Person whose Skeleton was Found in the Tomb." In The Tomb of Queen Tiyi, edited by Theodore M. Davis, XXIII-XXIV. London: Constable, 1910.

- _ . The Royal Mummies. Cairo: Service des Antiquités de L’Égypte, 1912.

- _ Tutankhamen and the Discovery of his Tomb. London: George Routledge \& Sons, 1923.

- Strouhal, Eugen. "Biological Age of Skeletonized Mummy from Tomb KV 55 at Thebes." Anthropologie: International Journal of the Science of Man 48 (2010): 97-112.

- "The Mystery of Tutankhamun's Tomb." Medical News, January 3, 1969.

- "Tutankhamun: The Face Behind the Mask." The Sunday Times, March 26, 1972.

- Tyldesley, Joyce. Tutankhamen's Curse: The Developing History of an Egyptian King. London: Profile, 2012.

- "Violent Death of Tutankhamen." The Times, October 25, 1969.

- Woodward, Scott. "Genealogy of New Kingdom Pharaohs and Queens.” Archaeology 49 (1996): 45-47.

الملاخ، كمال، "سر وفاة نوت عنخ آمون الذى يحير علماء الآثار،" الأهرام، 11 ديسمبر 